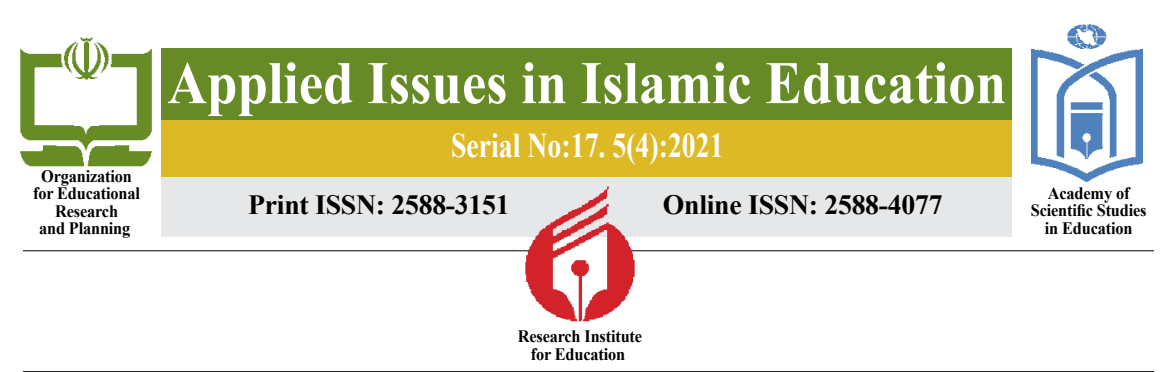

\title{
The Qualitative Study of the Sharing Model in Counseling with Islamic Approach and its Role in the Stability of the First, Second and Third Types of Changes in Clients
}

\author{
"Masoumeh Esma ${ }^{\circ}$ Mly $^{1} \quad$-Kowsar Dehdast ${ }^{2} \quad$-Shahab Qobadi ${ }^{3} \quad$ - Mohammad Asgari $^{4}$
}

Objective: Many models of counseling have been used in the prevention, development and treatment of clients. One of the new consulting approaches is Esma'ily (2014) sharing model based on Islamic ontology. The purpose of this study is to explain the components and investigate the role of consultants' sharing style in order to create sustainable changes of the first, second and third types in clients.

- Method: For this purpose, we used the grounded theory research method. The sample consisted of 5 counselors and 6 clients who used semi-structured interviews to extract experience-based perspectives.

- Finding: The obtained model includes the underlying factors and strategies and the central phenomenon in the realization of the sharing style. The central phenomenon in the realization of balanced sharing style is composed of attitudinal, functional and communication components. Creating awareness and perception of being centered on the axes of the role of creation, good creativity and purposeful expansion is the underlying factor of a balanced sharing style. The therapist's focus on the role of clients in existence, ontological evaluation, and preparation for the future constitute strategies for achieving a balanced sharing style.

- Conclusion: The present study shows that using the sharing model to bring about change can be a good predictor for greater stability in a variety of changes. In addition, due to the fact that the client reaches a higher level of self-awareness and self-coordination with the components of existence, they can act as their own consultant.

Keywords: sharing style; change stability; first, second and third type of change.

Citation: Masoumeh Esma'ily., \& Kowsar Dehdast., \& Shahab Qobadi., \& Mohammad Asgari. (2021). The Qualitative Study of the Sharing Modelin Counseling with Islamic Approach and its Rolein the Stability of the First, Second andThird Types of Changes in Clients. Applied Issues in Islamic Education, 5(4): 7-32.

Received: $2021 / 01 / 03$

Accepted: $2021 / 02 / 22$

1. A Professor in Counseling, the Department of Counseling, the Faculty of Psychology and Education, Allameh Tabataba'i University, Tehran, Iran.

E-mail: masesmaeily@yahoo.com. (iD) 0000- 0002-8907-6145

2. Corresponding Author: A Ph.D. in Counseling, the Department of Counseling, the Faculty of Refah, Tehran, Iran. Research.

E-mail: dehdast92@gmail.com. (D) 0000-0001-5690-201X

3. A Ph.D. student in Counseling, the Department of Counseling, the Faculty of Psychology and Education, Allameh Tabataba'i University, Tehran, Iran.

E-mail: drmasgari@atu.ac.ir. (D) 0000- 0003-3549-594X

4. An Associate Professor in Evaluating and Measuring, the Department of Evaluating and Measuring, the Faculty of Psychology and Education, Allameh Tabataba'i University, Tehran, Iran.

E-mail: gh_sh121@yahoo.com. (DD 0000-0003-0226-175X 



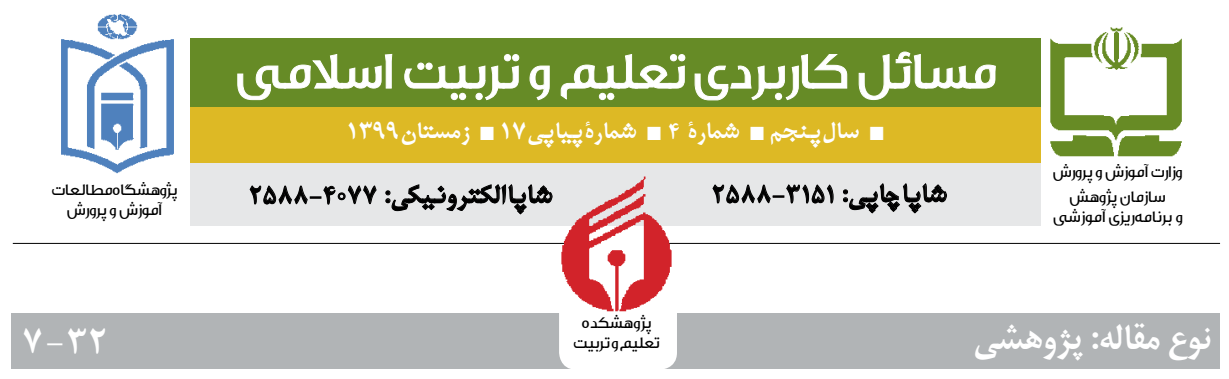

\section{مطالعه كيفى الخَوى سهر تَذارى در مشثاور

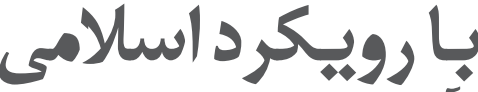 و نتثن أن در يايدارى تنغييبرات نوع اول، دوم و سوم مر اجعان}

$$
\text { كوثر دهدست" }
$$

معصومه اسمعيلىى"

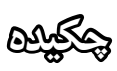

ه هدف: هدف اين يثروهش تبيين مؤلفه ها و بررسى نقش سبك سهممَذارى مشاوران بهمنظور

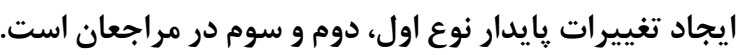

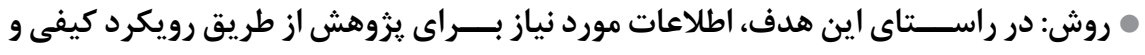

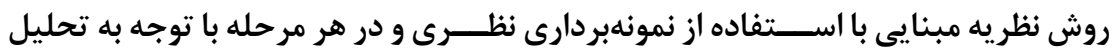

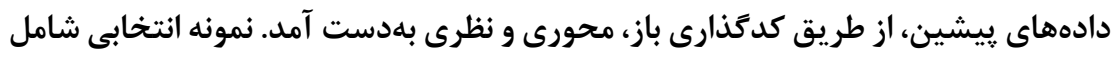

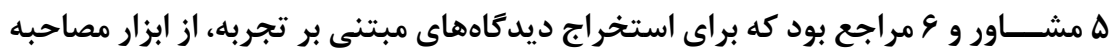
نيمهساختار مند استفاده شد.

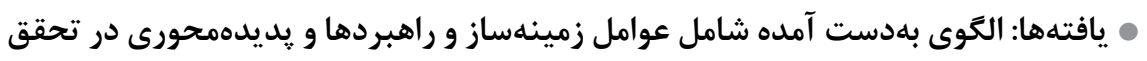

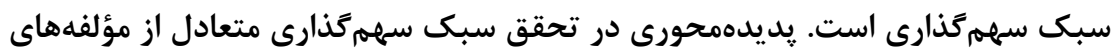

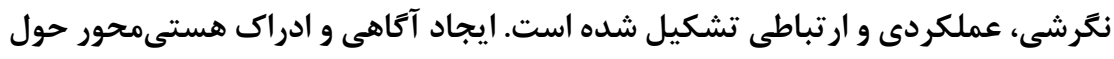

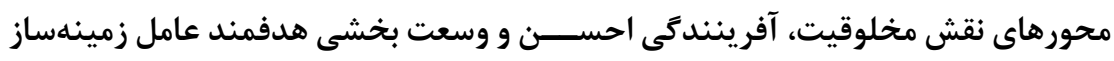

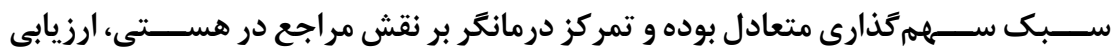
H

\section{ه تاريخ هذيرش:}

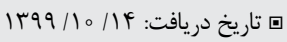

* استاد مشاوره، دانشكده روانشناسى و علوم تربيتى، دانشعاه علامه طباطبايى، تهران، ايران. Email: masesmaeily@yahoo.com (iD) 0000-0002-8907-6145

Email: dehdast92@gmail.com (iD) 0000-0001-5690-201x

*** نويسنده مسئول: دكتراى مشاوره، دانشكده رفاه، تهران، ايران. *****: دانشجوى دكترى مشاوره، دانشكده روانشناسى و علوم تربيتى، دانشعاه علامه طباطبايى، تهران، ايران. Email: gh_sh121@yahoo.com (D) 0000-0003-3549-594x

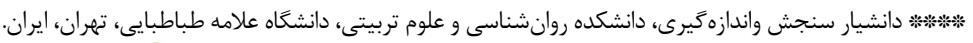
Email: drmasgari@atu.ac.ir (iD) 0000-0003-0226-175x 
هستى تر ايانه و آمادهسازى او براى رويارويى با آينده راهبردهاى تحقق سبك سههمخذارى متعادل را تشكيل ميى دهند.

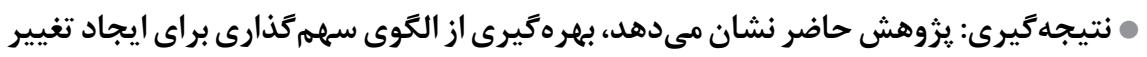

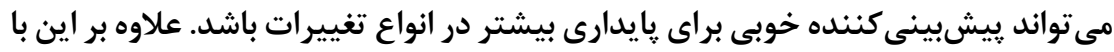

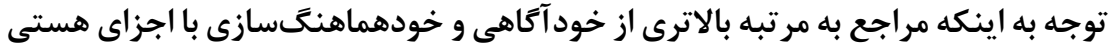
مىرسد، مى تواند خود بهعنوان مشاور خود عمل نمايد.

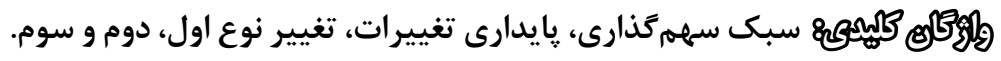

\section{بيان مسأله}

تغيير' فرايندى برنامهريزى شده و اصولى نظام مند است كه با بهرهخيرى از ارزشها و اصول علم روانشناســى، در يى ايجاد اثربخشــى عملكرد بوده و مستلزم آكاهىهاى

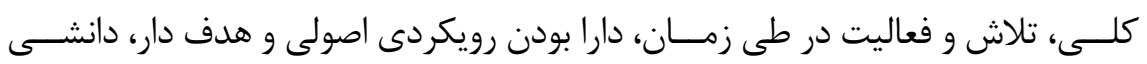
معتبر در مورد يويايىهاى انســان و جگگونكى تغيير در آنها است كه از طريق رهنمودها و فعاليتهاى ايجاد تغيير كه هدف آنها رفع مســأله و مشكل شخص در شرايط خاص و مسألهساز است، به كار گرفته مىشود (Wendell, Cecil \& Robert, 2004) و بهطور واضح و يا بهصورت ينهان تنها نتيجه مطلوبى است كه در روند مشاوره مىبايست اتفاق بيفتد. يعنى مشاوران فارغ از اينكه از جه نظريهاى پيروى مى كنند و يا جه نوع فضايى را همراه مراجع خود ايجاد مى كنند، دنبال تغيير هستند. در اين زمينه بررسى ها نشان مى دهد بين اهداف خوب و نتايج عالى، تغيير برنامهريزى شده شامل نه تنها داشتن ليستى از وظايف مورد نظر براى تغيير، بلكه ارائه جشمهاندازى از آنجه بايد تغيير كند و جگگونكَى ايجاد آن است، كه ماحصل آن بهبود ساز گَارى و تطبيق بين افراد و محيط ييرامون است (Funnell \& Rogers, 2011). لذا توجه به سطوح متفاوت تغييـــر كه در آن وضعيت جديد مطلوب با وضعيت ســابق، بهطور گايدارى فرق كرده و زمينه عملكرد مؤثرتر فرد در زندگى شخصى و اجتماع شده، حائز اهميت مىباشد. زيرا يك مشاور يا روان شناس تغييرات مذكور را با الخوهاى مشاورهاى متفاوت، در اين سطوح

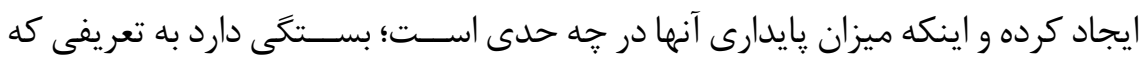


از ســـوح و خحَونكَى ايجاد تغييرات مى كند و در نتيجه اتخاذ الكَو و رويكرد درمانى در فرايند مشاوره كه زمينهايجاد تغييرات پايدار در مراجعان گردد، بسيار با اهميت و ضرورى

(Watzlawick, Weakland \& Fisch, 1974) سيســـم قادر است از دو طريق تغيير كند: تغيير مرتبه اول و دوم. زمانى كهايجاد تغيير

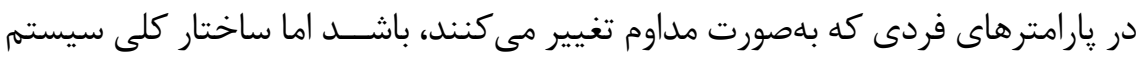

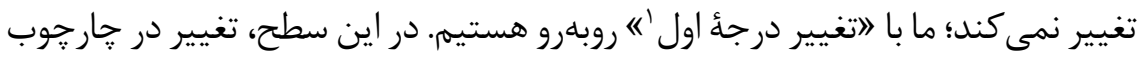

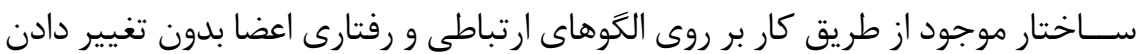

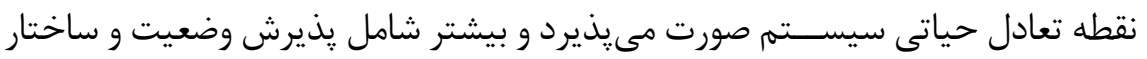

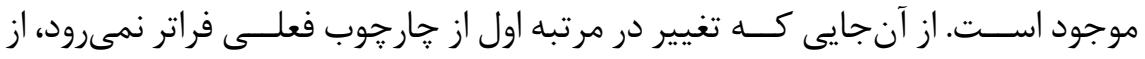

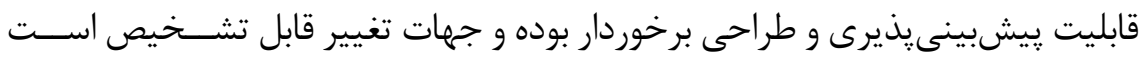

.(Van de Ven \& Poole, 2013)

اين ســطح از تغيير رويكردى محدود كننده به انســان اسـت زيرا او را در خارادايم

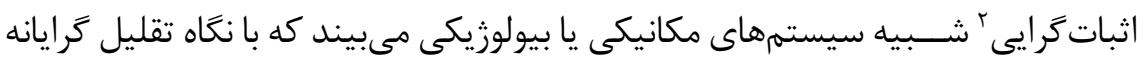

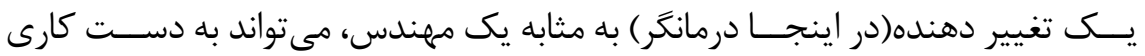
الكوهــــاى رفتارى و عملكــــدى او در همان زمينه و قواعد موجود، اقدام كند و تغيير نيز

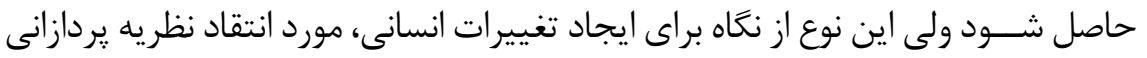

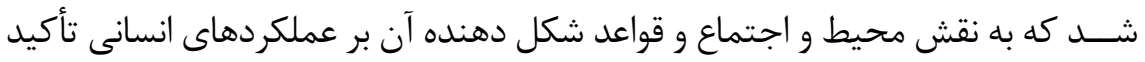

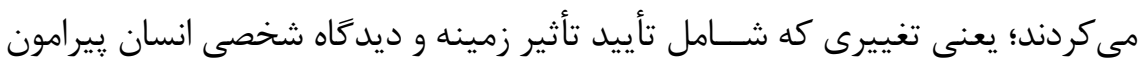

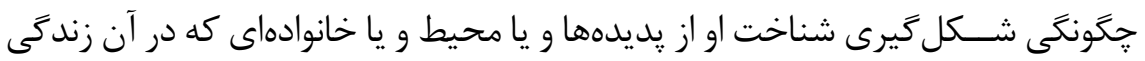

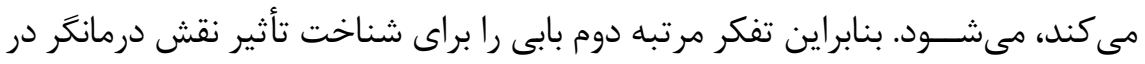

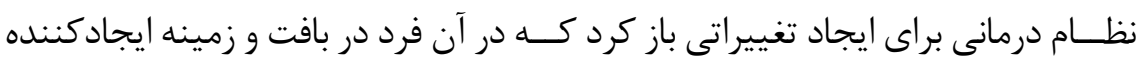

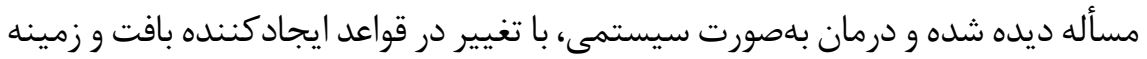
آسيبزا، تعريف مىشود (Dikerson, 2014). 
به اين معنا كه در اتغيير درجهُ دوم"' سيســتم بهصورت كيفى و ناييوســته تغيير مى كند. اين نوع دوم از تغيير سيســتمها، با لاتغيير در بدنهُ قوانين حاكم بر ســاختار يا

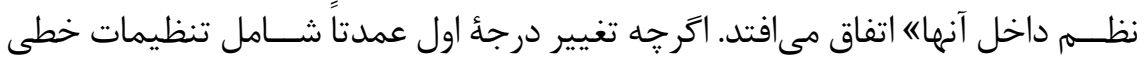
بدون عارضه اســت، تغيير درجهُ دوم بهعنوان يك ســاختار غيرخطى، وسيع، عميق يا تغيير هســتهاى در يك فرد توصيف مىشود. اين تغيير، نه سطحى است و نه محيطى، و از يك ســازگًارى جزئى با مسئله تشكيل نمى شود. در عوض، اين يك تجديد ساختار

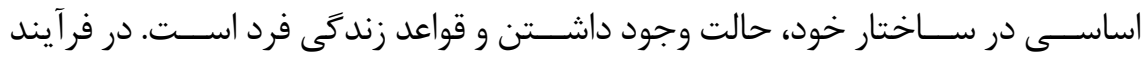
تغييـــر درجهُ دوم، اغلب تعادل فرد مورد تهديد واقع شـــده و اين تغيير مىتواند همراه با عوامل تنــشزاى محيط يا درگيرىهاى داخلى به ميزان قابل توجهى باشــد. جنـين شـــرايطى مى توانند بهعنوان كاتاليزور تغيير درجهُ دوم باشند (Stern \& William, 2007). يعنى اين گونه مى توان نتيجه گرفت كه تغيير درجهُ اول اغلب با حل مســـله و كاهش نشــانهها همراه است. در مقابل، تغيير درجهُ دوم بهعنوان تغييرى تعريف مىشود كه در آن ساختار اساسى سيستم مورد بازنخرى قرار مى گيرد؛ بهَّونهاى كه علاوه بر حل مسئله و كاهش نشانهها، سيستم بهطور دائمى بلهصورت ساختارى تغيير كرده و طراحى مجدد مىشــود. اين تمايزات در ســطح تغيير مىتواند براى سيستم فرد و همجنين سيستم خانواده اعمال شود (Murray, 2002). ولى زمانى نياز مىشـــود كه تغيير در نظام ارزشى و نخرشى فرد همراه شود. بنابراين سازهر ايان اجتماعى `در يك جابهجايى يارادايميكى تغيير مرتبه سوم را مستلزم تغيير

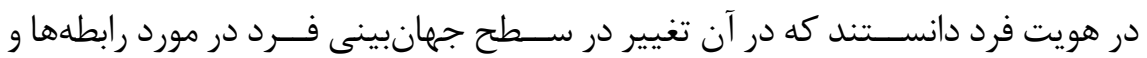
زندكَى كلى افراد اتفاق مى افتد كه متفاوت از تغييرات مرتبه اول و دوم است زيرا ارزشها و نخرش هاى فــرد را تحتتأثير تغييرات قرار مى دهـــد (Tsoukas \& Papoulias, 2005). تغييرات در اين ســـح مداخلاتى رادر بر مى گيرد كه در گستره بزرگترى از ارتباطات اتفاق مى افتد و شــامل زيرنظركرفتن منتقدانه ارزشها، باورها، و وابستخىىهاى متقابل فرد با محيط و اجتماع اســت. بدين طريق نارسايىها در الكوهاى موجود آشكار شده و الكوهاى جديد برنامهريزى مىشوند و در نتيجه شامل باز آرايى در مقياس بزرگ مى شوند 
(Reynante, Bratton \& Hein, 2017) اتفاق مىافتد كه طرحها يا جارجوبهاى جديد، تماماً در سيستم اعتقادى و هويتى فرد نهادينه مىشود كه بيانگر يك تغيير يار ادايميك است (Bess, 2006). ييامد عزيمت از تغيير مرتبه اول و دوم به تغيير مرتبه سوم، مستلزم تغيير در ديد و معانى افراد و درنظركرفتن زمينه اجتماعى و ســازوكارهاى گفتمانى دربر گيرنده آنها اســت (Mcdowell, Knudson \& Bermudez, 2019) كه با اتخاذ نوعى نغاه و جهانبينى جديد، بر فراروايتهايى كه افراد زندگىشــان را بر اساس آن تنظيمم و تنسيق مى كنند، تمركــز مى كند. در نتيجه در اين مرتبه از تغيير، شــيوه نتحـــرش و تفكر فرد تغيير رِيدا

مى كند (Tsoukas \& Papoulias, 2005). بر اين اســاس تفكر مرتبه ســـوم به درمان گرانى نياز دارد كه از طريق مشـــاركت و آ همراهى با مراجع، باعث ايجاد فراديدگاهى ' در آنها مىشوند كه طى آن به تأثير ارتباطات كسترده تر شامل سيستمهاى اجتماعى و يويايى هاى قدرتى و معانى جمعى يبى برده و به مرور جهانبينى گستردهترى از ارتباطات در زندگى يى ببرد (Mcdowell et al, 2019). در اين حالت تمر كز درمان بر فرا روايتها رفته و مفروضات مراجع ييرامون فرهنگ، سيستم اجتماعى و قدرت در روابط خانواده و ارائه مشكلاتشــان توسط درمانَّران، مورد بررسى قرار مى گيرد لذا براى موفقيت آميز و يايدار بودن اين تغيير نياز به تغيير در فرهنگ، رفتار و ديدگاه حاكم بر ذهن اسـت (Mcdowell, 2015) بهَّونهاى كه اخر اين تغيير بهصورت صحيح انجام شود نشان مىدهد كه فعاليت هوشمندانهاى روى نحوه بودن و هويت فرد اجرا شده است (ارمغان، سوس (). بنابراين ضرورى است كه انسانها و بهخصوص مشاوران بهعنوان يكى از مجريان اين تغيير، براى مؤثر و يايدار بودن، آنها را تشخيص دهند؛ برايش برنامهريزى كنند و ساز گار با آن حركت نمايند (Balauch, 2019 Akingbola, Rogers \&). در ايــن خصوص يزوهشها نشــان مىدهد رواندرمانى و مشــاوره براى ايجاد اين

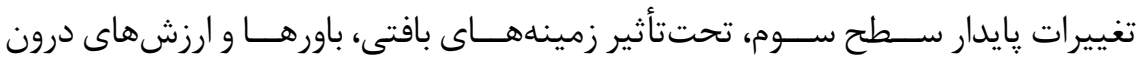
فرهنخــى مراجعان قرار دارد و كارايى آنها به ميزان توجه به اين هماهنگى و ســاز گارى بستخى دارد (Hofmann, 2006) در نتيجه همين امر باعث شده در كنار ظهور نظريههاى مختلف مشــاوره و رواندرمانى، معنويت و مذهب در حال تبديل شـــن به يك مفهوم 
جند بعدى با معنىى باشــد كه در فرهنَـها و موقعيتها و نحوه ارتباط آن با ســلامتى و بيمارى روانى مورد بررســىهاى زيادى قرار گرفته اســت (براى مثــال ثناگويىزاده،

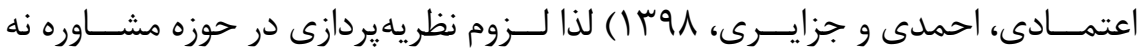

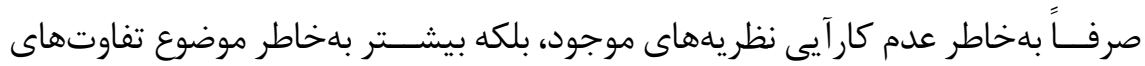

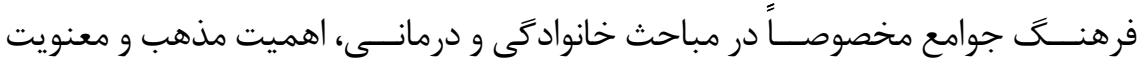
در ســلامتى انســانها و ضرورت نوآورى در اين حوزه علمى است كه همين امر زمينه

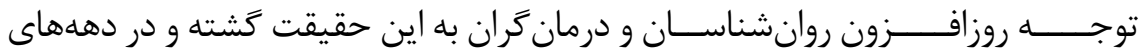
اخيـر، درمانگران به روش هاى درمان يكيار جه و موضوع دين توجه جدىترى داشتهاند (براى مثال Sankhe, Dalal, Agarwal \& Sarve, 2017 و شكل گيرى رويكردهاى مشاورهاى (S) مبتنى بر هستى شناســى اســلامى، بهعنوان يكى الخوى دينى مدنظر قرار گرفته است. بررسى ادبيات تحقيق :يرامون جيستى مشاوره با رويكرد اسلامى نشان مى دهد اين

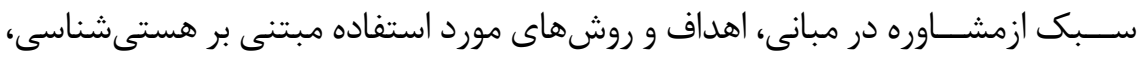

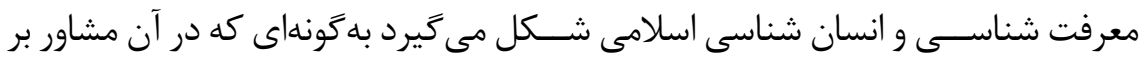
اســاس جهانبينى توحيدى، در ارتباط با مراجع، ســى در ايجاد تغييرات پايدار است (ثناگويىزاده، و\س|). در اين زمينه يزوهش هاى داخلى متعددى به تدوين رويكردهاى مشاوره و رواندرمانى اسلامى و ارزيابى اثربخشى آن يرداختهاند (براى مثال انصارى، جان

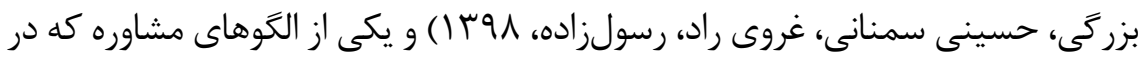
حل مسائل بين شــخصى مبتنى بر مبانى و اصول و طرح كلى يارادايمم توحيدى درباره

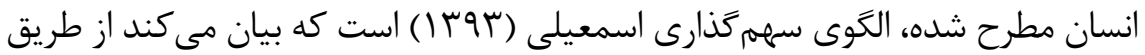
خودآكاه بخشــى ييرامون ارتباطات فرد با خودش، محيط و جهان هستى و با تمركز بر نقش خودش در اين جهان، مىتوان با ايجاد جهانبينى گســترده تر در مراجع، تغييرات يايدارترى را رقم زد.

رويكرد مشاور هاى سمهم گذارى برخاسته از هستى شناسى اسلامى و داراى ساختاراست و روابــط بين فردى و آموزش كفت و گوى مؤثر را بهعنوان يكى از اركان مهمم مى يذيرد.

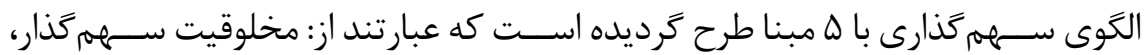
آفرينش احسن، پييوستخى و وسعت هستى، هدفمندى آفرينش و زوجيت. براساس اين رويكرد انسان سالم و غيرسالم بر ييوســتارى از تأله قرار خواهد داشت زيرا انسان سالم 
كسـى است كه اول، داراى شناخت صحيح از خود، جهان و خالق خود و هدف آفرينش

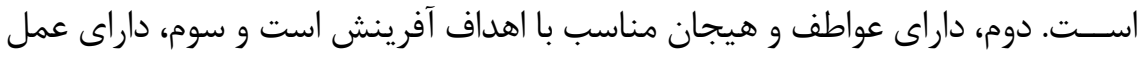

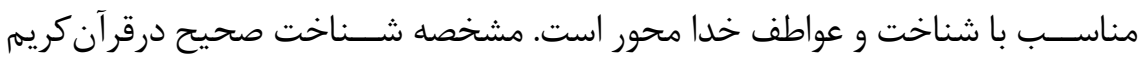

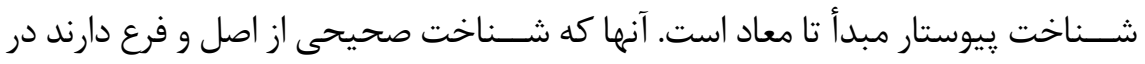

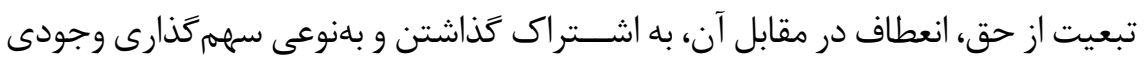

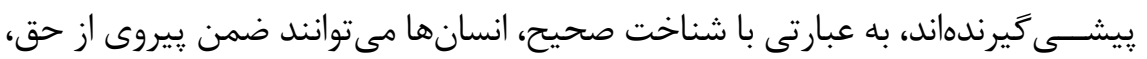
انعطاف داشته و هر كس براى رشد خود به اداى سهم خود در برابر ديكرى بيردازد. اين امر به اين معناست كه در اين الكو اسمعيلى(سوج ( ) تلاش كرده است با توجه به

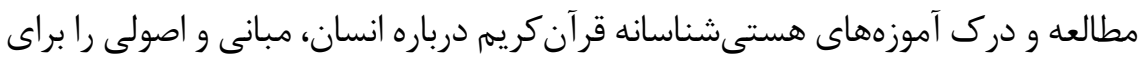

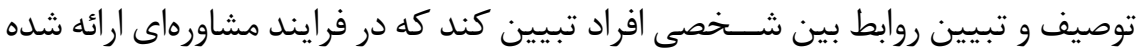
در الخو، مىتواند محوريّت بررسى و ارزيابى خايدارى تغييرات ايجاد شده در فرايند مشاوره باشد تا از طريق داشتن سبك سهم خذارى مؤثر مشاوران و مراجعان در ارتباط با يكديكر،

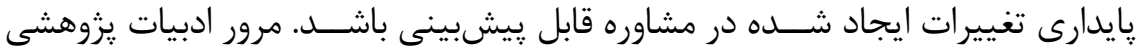

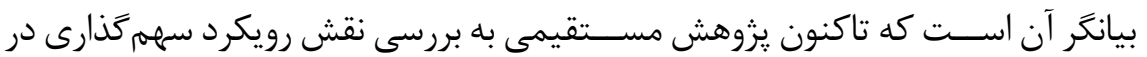

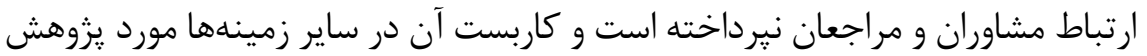
بوده است. بهعنوان مثال شعبانى (I IVY) طى يزوهشى به بررسى كيفى نقش كفتمان

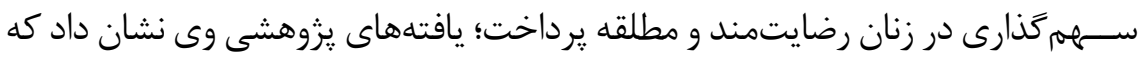

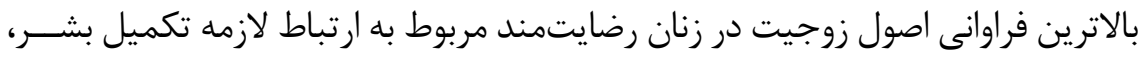

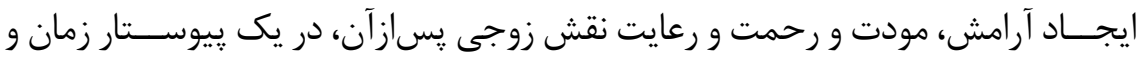

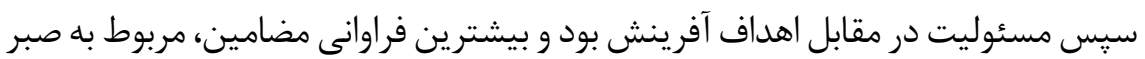

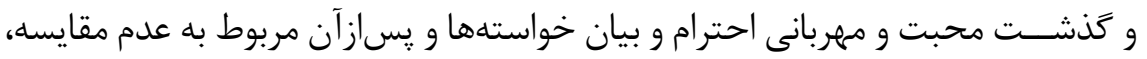
دلســوزى بر ناتوانى و كاستى، باور به نتيجه اعمال، تصميمَيرى از مرد و مديريت خانه

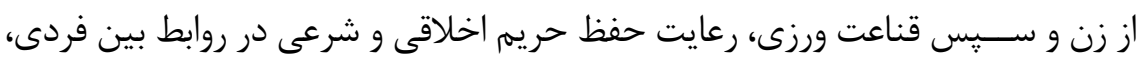

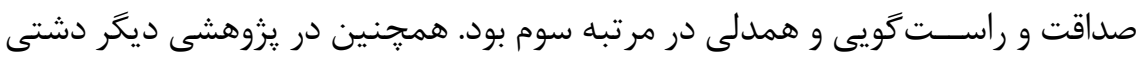

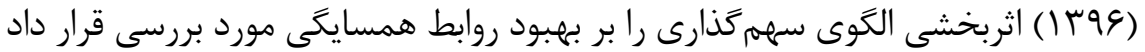

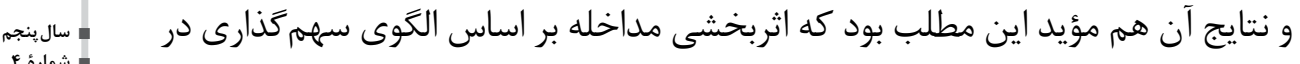

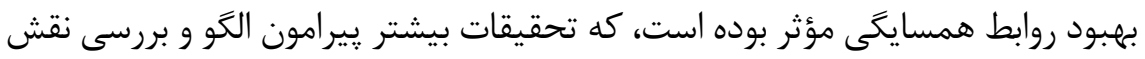


آن در ايجاد تغييرات هايدار در اتاق درمان و ســاير زمينهها بايد مورد توجه بيشــتر قرار بخَيرد. لذا در تحقيق حاضر در نظر داريم از طريق ياســخ به سه سؤال يُروهشى در ابتدا به تبيين مؤلفههاى ســبك سهرمخذارى متعادل و مؤثر مشـــاوران در ارتباط با مراجعان

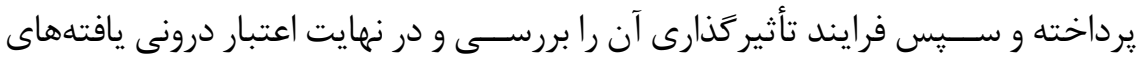
تحقيق بر اساس نظر صاحبنظران ارزيابى شود تا به اين ترتيب ميزان هايدارى تغييرات نوع اول، دوم و سوم در آنها قابل ييشبينى باشد.

\section{روش تحقيق}

يزوهش حاضر در قالب رويكرد كيفى و با اســـفاده از نظريه زمينهاى ' صورت گرفته اســت. دليل انتخاب اين روش آن بود كه اطلاعات در قالبى منسجمم حول محور سبك مشاورهاى مؤثر در ايجاد تغييرات يايدار در مراجعان وجود نداشت، لذا تلاش شد با روش علمى و تلفيق روش اســتقرايى و قياسى اطلاعات را از طريق مصاحبه مرحله به مرحله بلهدست آورده و در نهايت در قالب يك الگوى مفهومى اطلاعات را منسجم و ارائه كنيهم. نمونه ₹يرى در روش گراندد تئورى، بلصورت هدفمند و در دســترس بوده و مبتنى بر تجربه زيســـه مشـــاركت كنند نمونه مورد مطالعهاين يزوهش، از بين مشــاورانى كه بيش از دو سال سابقه كار داشته و تحت تعليهم الكوى ســـهمخذارى بودند، جهار نفر قرار گرفت كه با محوريّت بررسى آراء و متون و صوتهاى اسمعيلى در كارگاهها و كلاسهاى ايشان و مصاحبه با آنها انجام شد تا به ســـؤال هاى يثزوهشـــر ييرامون عوامل و راهبردهاى تحقق سبك سهرمخارى مؤثر ايجادكنـنده تغيير :ايدار در مراجعان، ياســخ دهند. عـلاوه بر اين بهنظر غنا ييدا كردن دادهها و تبيين مؤلفههاى ســـهمَذارى ايجاد كنـنده يايـــارى تغييرات، نمونه 9 نفر از مراجعينى قرار كرفتند كه در فرايند يك مشــاوره شركت كرده و تعداد جلسات به بيش موري از جهار، ادامه ييدا كرده بود به اين ترتيب كه اين ســؤالات در اولين مصاحبهها (هم از مشاوران و هم از مراجعان) براى روشنتر شدن موضوع، ييرامون "تجربه فرد (مراجع) از تغيير در فر ايند مشـــاوره" بود و به موضوعات اطراف اين محور از جمله" ميزان يايدارى اين تغييرات، عوامل ايجاد كنـنده تغييرات رايدار، راهبردهاى مشـــاورهاى بلوجودآورنده 
آن، نقش مشــاور و مراجع در شــكل خيرى اين تغييرات و ســـــ مشاورهاى و ارتباطى آنهاه يرداخته شد اين مصاحبهها تا جايى ادامه يافت كه ياسخها به اشباع رسيدند. مدت

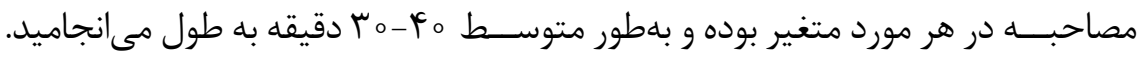

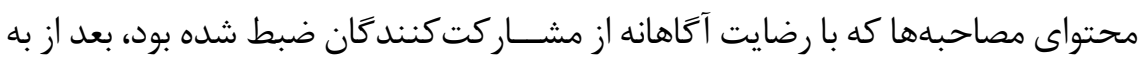
يايان رســـيدن به متن نوشتارى تبديل شدند و از طريق كدگذارى متن (دادهها) طى سه

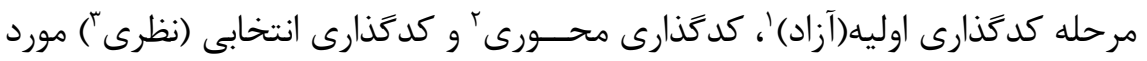

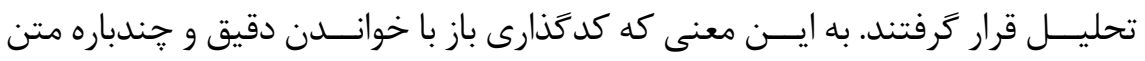
شروع شد و در خلال اين مطالعه، واحدهاى معنادار شناسايى، و با يك مفهوم نامخذارى مىشدند. نتيجه كدگذارى باز، مجموعهاى از مقولات مفهومى ايجاد شده از دادهها بود. كدَّــارى محورى نيز فرايند ايجاد ارتباط و ييوند بين مقولههاى اصلى اســت كه در كدگذارى باز، شناســايى و تعريف شدهاند. دراين مرحله، ييوندهاى حشو و زائد بين مقولات را حذف كــــده و الخوهاى ارتباطى منطقى بين مقولههــــا برقرار مى كرديم. در

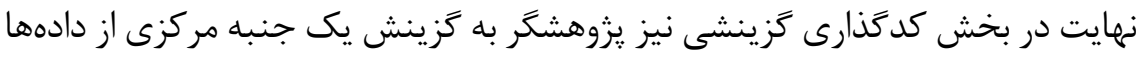
بهعنوان مقوله هستهاى مبادرت ورزيد و روى آن متمر كز شد. در كدگذارى انتخابى، هدف يكيار جهسازى و در كنار هم قرار دادن فرضيهها و گزارههاى بهدست آمده و تحليل است. مقوله هاى هستهاى عموماً يك موضوع مركزى در دادهها هستند كه بهنظر يكيار جهسازى مقولههاى ديخر در دادهها در ســـح بالاترى از انتزاع ساخته مى شىوند، و قدرت توضيح مؤلفهها و ابعاد احصا شده در كدهاى محورى را دارند

\section{يافتهها}

در فرايند مصاحبه با |F مشــاور و 9 مراجع كه در يزوهش مشاركت داشتند، مفاهيم مؤثر در بر گيرنده فرايند شــكل گيرى تغيير يايدار در شكل ا و جداول r و نشان داده 
جدول ا. ويزَّى هاى جمعيت شناختى مشاوران و مراجعان حاضر در مصاحبهها

\begin{tabular}{|c|c|c|c|c|c|}
\hline جنسيت & وضعيت تاهل & سن & تحصيلات & 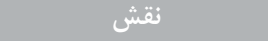 & رونف \\
\hline 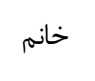 & متأهل & $\Delta V$ & استاد تمام & مشاور با رويكرد سهممَذارى & 1 \\
\hline خانم & متأهل & ra & دكترا & مشاور با رويكرد سهمثذارى & $r$ \\
\hline خانم & متأهل & fr & دانشجوى دكترى & مشاور با رويكرد سهممخذارى & $r$ \\
\hline خانم & متأهل & 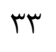 & دانشجوى دكترى & مشاور با رويكرد سهممخارى & F \\
\hline 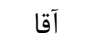 & مجرد & rq & كارشناسى ارشد & مراجع & $\Delta$ \\
\hline 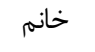 & متأهل & $\Delta f$ & كارشناسى ارشد & مراجع & 9 \\
\hline 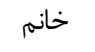 & متأهل & $\Delta 1$ & كارشناسى ارشد & مراجع & V \\
\hline 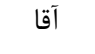 & مجرد & r & كارشناسى ارشد & 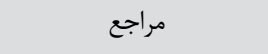 & $\Lambda$ \\
\hline خانم & مجرد & rV & دانشجوى دكترى & 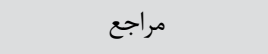 & 9 \\
\hline 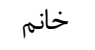 & مجرد & 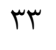 & كارشناسى & مراجع & 10 \\
\hline
\end{tabular}

سؤال أول هُؤهش: : مؤلفههاى سبك ســـهمَذارى متعادل مشاوران در ارتباط با 


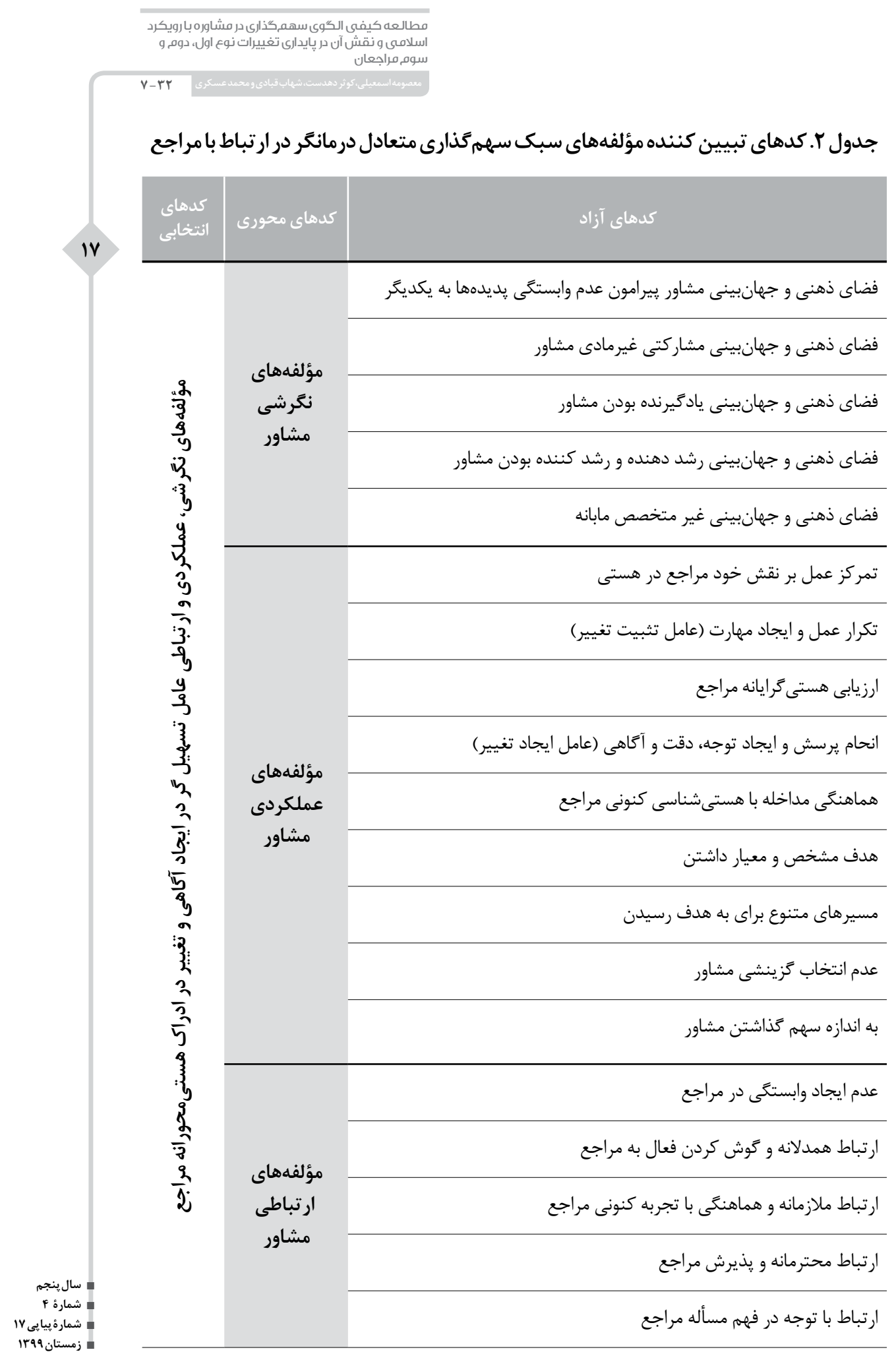


جنانجه در جدول r آمده و در جدول ب در ادامه نشــان داده مىشـــود، المؤلفههاى سبك سهمزگذارى متعادل مشاور در ارتباط با مراجعانه در يك مدل فرايندى با عوامل زمينهســاز تحقق سبك ســـهمخذارى متعادل و راهبردهاى ايجاد كننده آن با يكديخر

مرتبط شدند. كه در ادامه به شرح مختصرى از اين مؤلفهها يرداخته مىشود:

\section{مؤلفهایى سبك سهرمَذارى متعادل درمانگًر در ارتباط با مراجع مؤلفه هاى نكرشى}

نگرشهاى مشاور در محيط درمان بهعنوان عاملى ينهان كه هدايت گر رفتار مراجع است تلقى شده و در سبك سهمزَّارى شامل عناصرى است كه در كدهاى آزاد و محورى خود را نشان داد. به اين ترتيب كه كد محورى مؤلفههاى نخرشى مشاور از له بعد؛ الفضاى ذهنى و جهانبينى مشــاور ييرامون عدم وابستخى يديدهها به يكديخره، الفضاى ذهنى و جهانبينى مشــار كتى غيرمادى مشاور"، افضاى ذهنى و جهانبينى ياد گيرنده بودن مشــاور"، افضاى ذهنى و جهانبينى رشد دهنده و رشد كنـنده بودن مشاور"، افضاى ذهنى و جهانبينى غير متخصص مابانه بودن مشاوره تشكيل شده است.

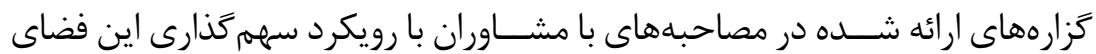

$$
\text { ذهنى را بدينصورت بيان مى كرد: }
$$

افضا يیى كه بر ذهن ما بهعنوان مشــاور حاكم است، بر نوع تصميهميرى و عملكرد

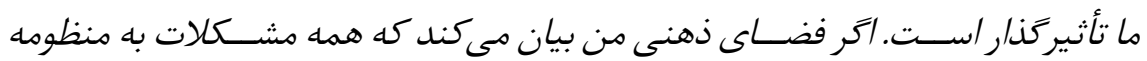

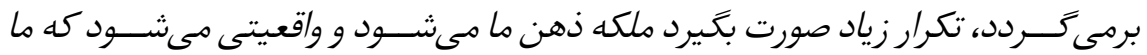

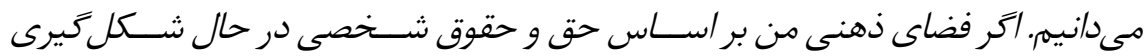
باشد. /ين يرانتزهاى ذهنى شكل كرفته شده باعث مىشود منطبق بر آن عملكردهايمر و راهبردهايهم و تشخيصم و /رتباطم با مراجع شكل بخيرده. يس نوع بودن مشاور و نوع فهمم و زبان و تفكر و ساختارها و قواعدى كه در فضاى ذهنى او حكم فرما است بر رابطه او با مراجع تأثير مى گذارد و راهبردهاى او را تحت تأثير قرار مى ودهد.

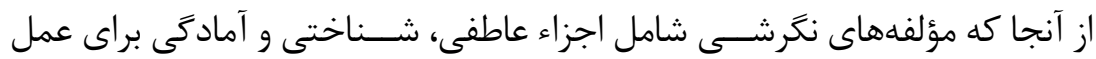
مىشود، نخرشهاى مشاور فضاى آميختهاى از معانى ذهنى و مفهومى را شامل مىشود. اگر زبان و تفكر و تجربه مشــاور بر هستى شناسـى ســـهم گذارانه يايهريزى شده باشد، 
نَاشتى كه بين ذهن مشاور و مراجع انجام مىشود بر مبناى رويكرد سهمرَذارانه انجام

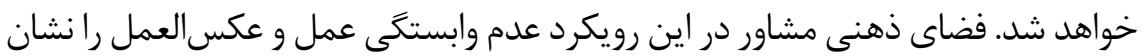

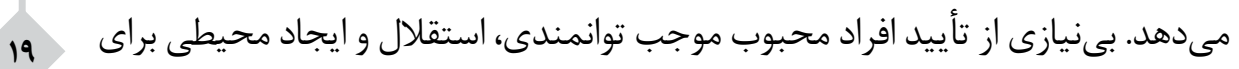

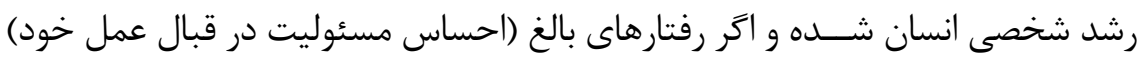

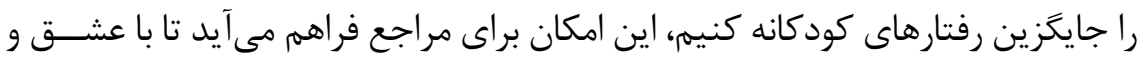
محبت بيشترى به انجام امور بيردازد.

\section{مؤلفهاى عملكردى}

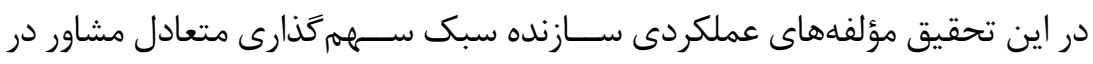

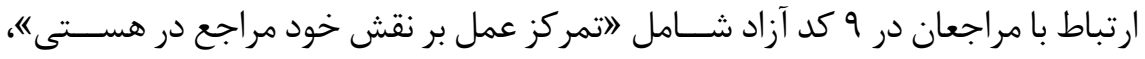

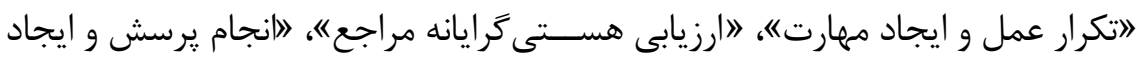

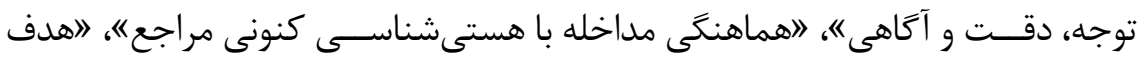

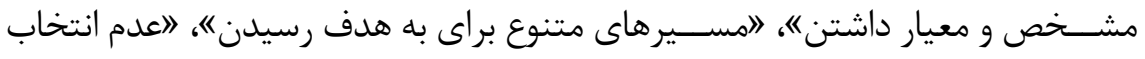

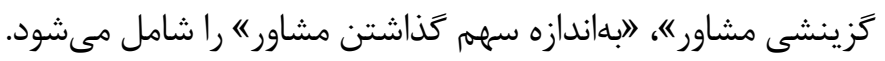

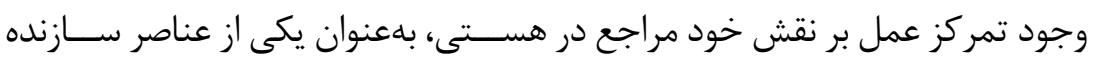

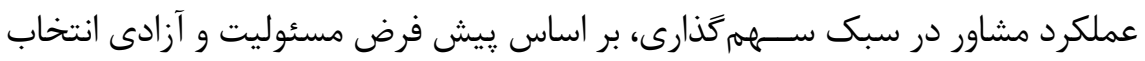

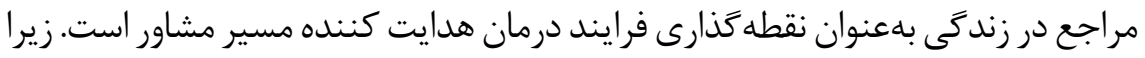

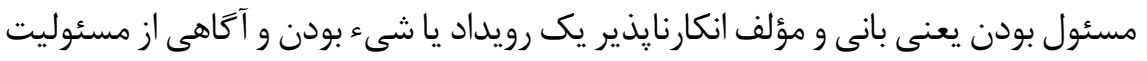

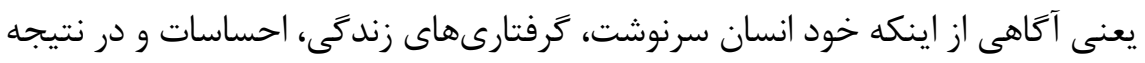

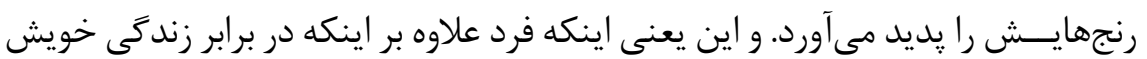

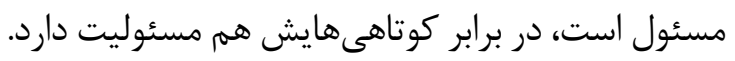

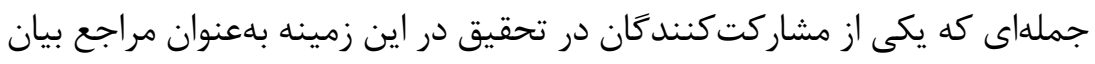

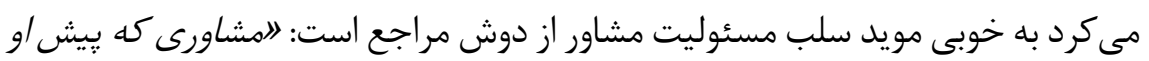

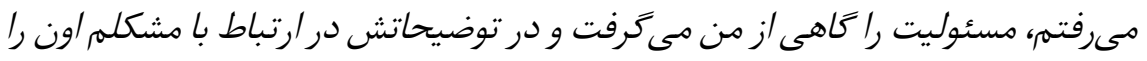

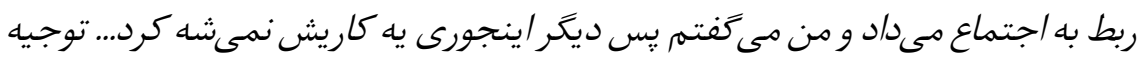

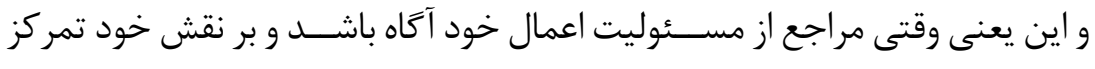




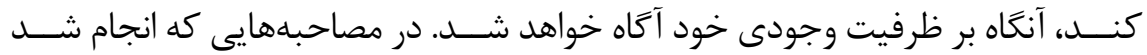
مراجعان وقتى بر نقش خود در مسائل يى مىبردند، احساس مى كردند كه بر زندگى خود تســلط دارند و مى توانند خود را اداره كنند و اين يكى از عناصر سازنده مؤلفه عملكردى در سبك سهمزَذارى مشاوران است.

\section{مؤلفههاى ارتباطى}

در تحقيق حاضر مؤلفه ارتباطى بهعنوان عاملى مؤثر در شكل گيرى سبك سمهمَذارى متعادل مشــاوران خود را نشان داده كه شامل عناصر زير است: العدم ايجاد وابستخى در مراجع "، ا|رتباط همدلانه و گوش كردن فعال به مراجع"، لارتباط ملازمانه و هماهنگى بــا تجربه كنونى مراجع"، لارتباط محترمانه و يذيرش مراجع"، لارتباط با توجه در فهمم

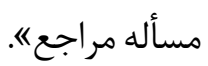

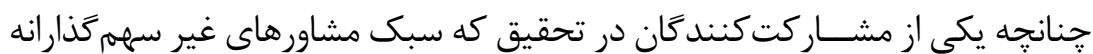
مشاور را توضيح مى داد، بيان مى كرد: "البهمون مى كفت با خودم كاركنيد. ولى آخرش كلاً رها كرد و حرفهاش خالصانه نبود "، كه درآن مشاور به مراجعان خود ييشنهاد همكارى مى دهد و اين باعث ايجاد رابطهاى دو Fانه فارغ از رابطه درمانى مىشود و فضاى شفا بخش درمان را به سوى حل مشكلات شخصى مشاور مىبرد. اما در جايى ديخرمؤلفه ارتباطى مشاور با سبك مـى

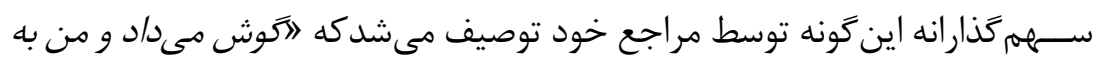
اين نتيجه رســـيده بودم كه داره به من كمك ميىكنه. رســيدكى از او شروع شل و

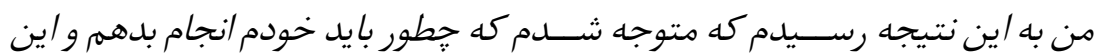

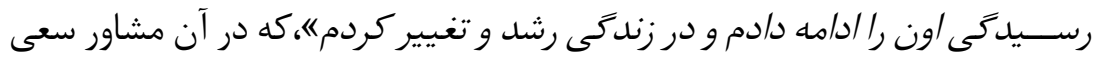
مى كنــد با گوش دادن فعال ارتباط درمانى صحيح با مراجع برقرار كرده و از طريق ملازمت و همراهى و ارتابط متوجهانه خود به مراجع، موجبات بالندگى و رشــداو را تسمهيل كند. 


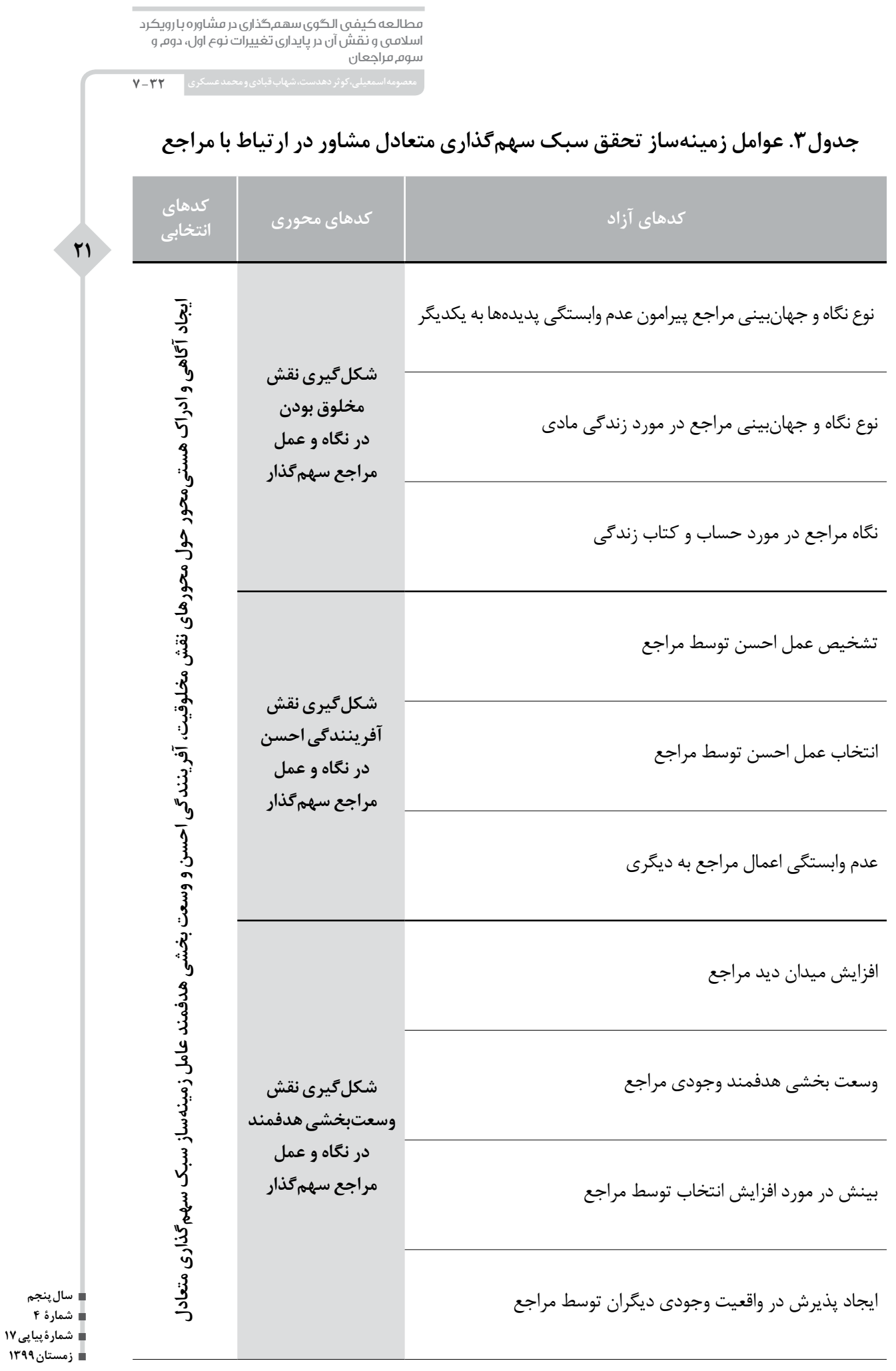


جدول F. كدهاى تبيين كننده راهبردهاى سبك سهم كذارى متعادل مشاور در ارتباط با مراجع

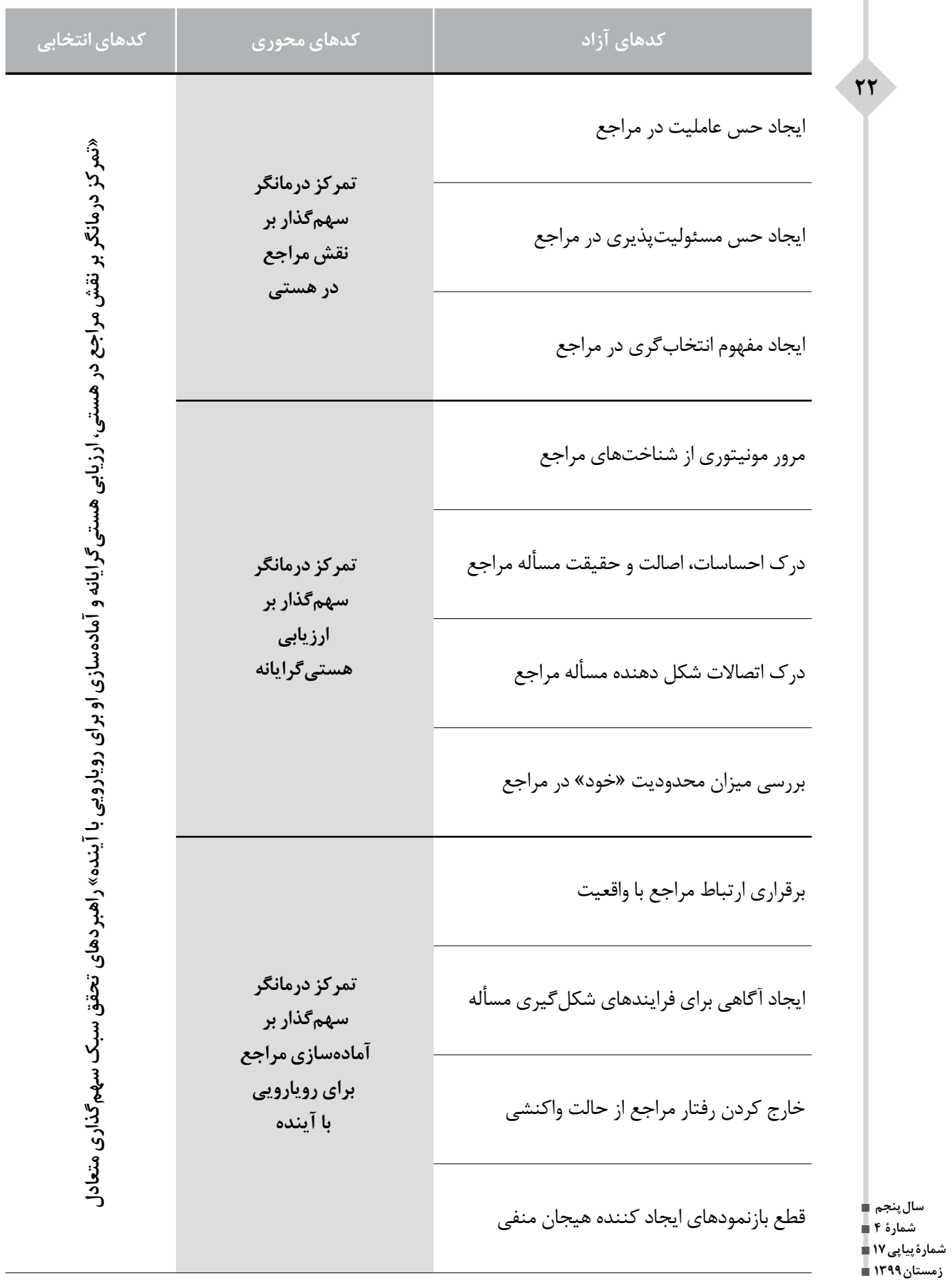




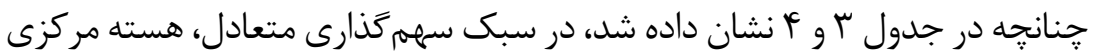
ايجاد تغيير بهعنوان عامل زمينهســـاز تحقق يايــدارى تغيير در مراجع لايجاد آكاهى و ادراك هستى محور حول نقش مخلوقيت، آفرينند در زندگى و در هستى 《 است. كه اين تغييرات حول محور آكاهى افزايى هستى محورانه بهنظر ايجاد تغييرات یايدار رخ مى دهد. يعنى آن جيزى كه يكى از مشاوران در يزوهش اين گونه توضيح داد: "وقتى

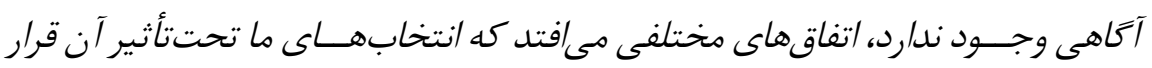

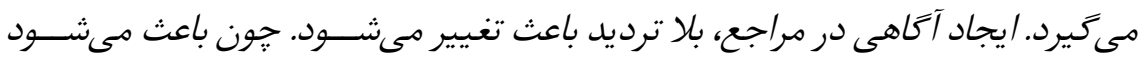
سازكاريش با هستى بالا رود و تفاوتهايى را هم كه وجود دارد را هم ببيند. و از احساس مراس

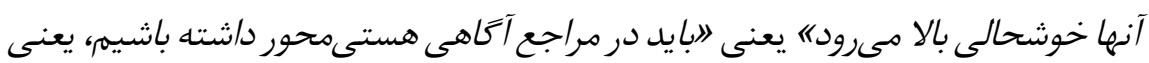
آكاهى درباره نقشهايش و تغييرى كه براى او وضعيت مطلوب / يجاد مىكند.كه در سطح آخر /ين آخاهى در/رتباط مراجع با هستى صورت مى كيرد." مصاحبه شونده ديخرى نيز

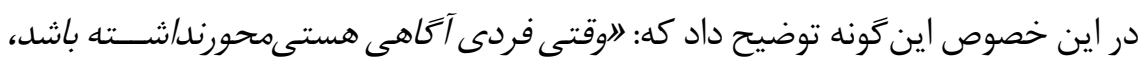
هميشــه حساب كتاب وجود دارد كه كجا به من برمى كردد؟ ولى در اين نوع از آكاهى، نخرش انسان آنقدر وسعت ِيدا مى كند كه بسيارى از بله بستانهاى مادى در اين جهان

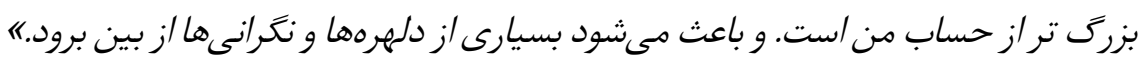
بر اين اســاس در فرايند مشاورهاى با سبك سهممَذارى، مشاور با كار كردن بر روى لرى

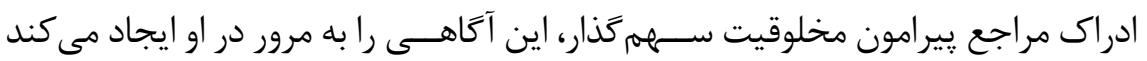
كه انســان مخلوقى است و خالقى دارد و خالق مالك است و مالك مربى، و خود فرد كه

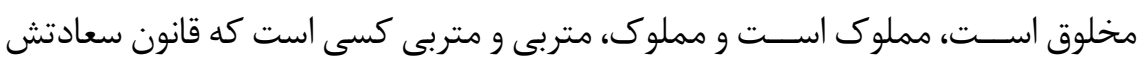

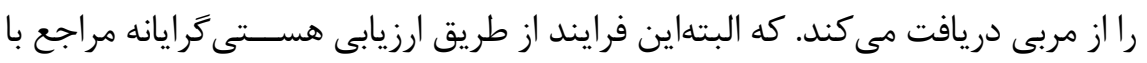
مرور مونيتورى از شناختهاى او و درك حقيقى اتصالات شكل دهنده مسأله او و ميزان

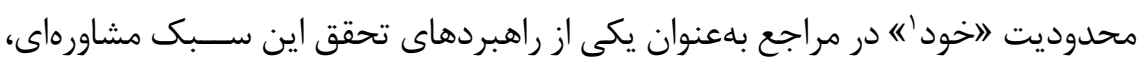

$$
\text { صورت مى خيرد. }
$$


در اين زمينه يكى از مشــاوران با رويكرد سهمزذارى توضيح مى داد: لادر اين رويكرد خودى مههم/ست كه بتواند همه دنيا را ببيند و/رتباط برقراركند. يس وقتى مراجع نمىتواند

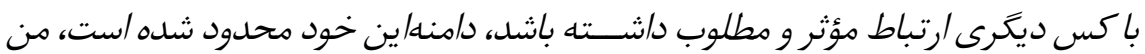
وجودش كوجگى مانده است و محدوديت من آفت و آسيب است و بايد روى آن كاركردها. نكته بعدى كه در اين سبك مشاورهاى بايد به آن توجه كرد اين است كه تمام هستى آفرينش احســن دارد، و به بهترين شكل آفريده شـــه است، مخلوق در نحوه زندىى و ارتباطش با ديخران و هر جزء هســتى، بايد به شيوه احسن عمل كند. اين امر به معناى آن اســت كه در سبك مشاورهاى سهمزَّارى، مشاور در ارتباط با مراجع او را به سمتى هدايت مى كند كه در هر ارتباطى بهترين و احسنترين انتخاب را براى انجام عمل داشته و اعمالش را بدون اينكه در ارتباط با كار طرف مقابل در نظر بخيرد، متمركز بر نقش خود صورت دهد. كه در اين حالت، به مرور نقطه تعادل تغيير كرده و سيستم در يك فرايند حلقوى تغيير خواهد كرد و در نهايت هدف آفرينش انســان كه رشــد و وسعت يافتكىى شخصى و اجتماعى است، نيز اتفاق افتاده و در عين حال آرامش شخصى و اجتماعى را هم در ارتباطات شاهد خواهيم بود.

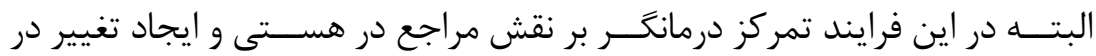
مسائل شكل گرفته شده از طريق تغيير نخرش ييرامون ايجاد عامليت در مراجع و حس مســــوليت يذيرى و انتخابكرى در او و كمك بهايشان براى رويارويى با آينده از طريق ارتباط دادنشان با واقعيت و ايجاد آكاهى درباره فرايند شكل گيرى مسأله و خارج كردن مراجع از حالت واكنشى رفتار كردن، در عملكرد او تغييراتى ايجاد مى كند كه در نهايت همين امر زمينهساز تحقق تغيير يايدار در او خواهد شد. در مدل مفهومى زير خلاصهاى از مباحث مطرح شــده بهصورت شمايى كلى به اين ترتيب نشان داده شده اســت كه عوامل على و بسترساز شكل گيرى سبك سهمرگذارى متعادل يعنى لايجاد آكاهى و ادراك هستى محور حول نقش مخلوقيت، آفرينـندى احسن و وسعت بخشى هدفمند مراجع" در تعامل با راهبردها و استراتزىهاى به كارگرفته شده جهت تحقق یايدارى تغييرات اتمر كز درمانگر بر نقش مراجع در هستى، ارزيابى گرايانه مراجع و آمادهازى او براى رويارويى با آينده الخوى مفهومى ايجاد تغيير يايدار سطح سوم از طريق سبك سهمخذارى متعادل مشاور را نشان مى دهد. 


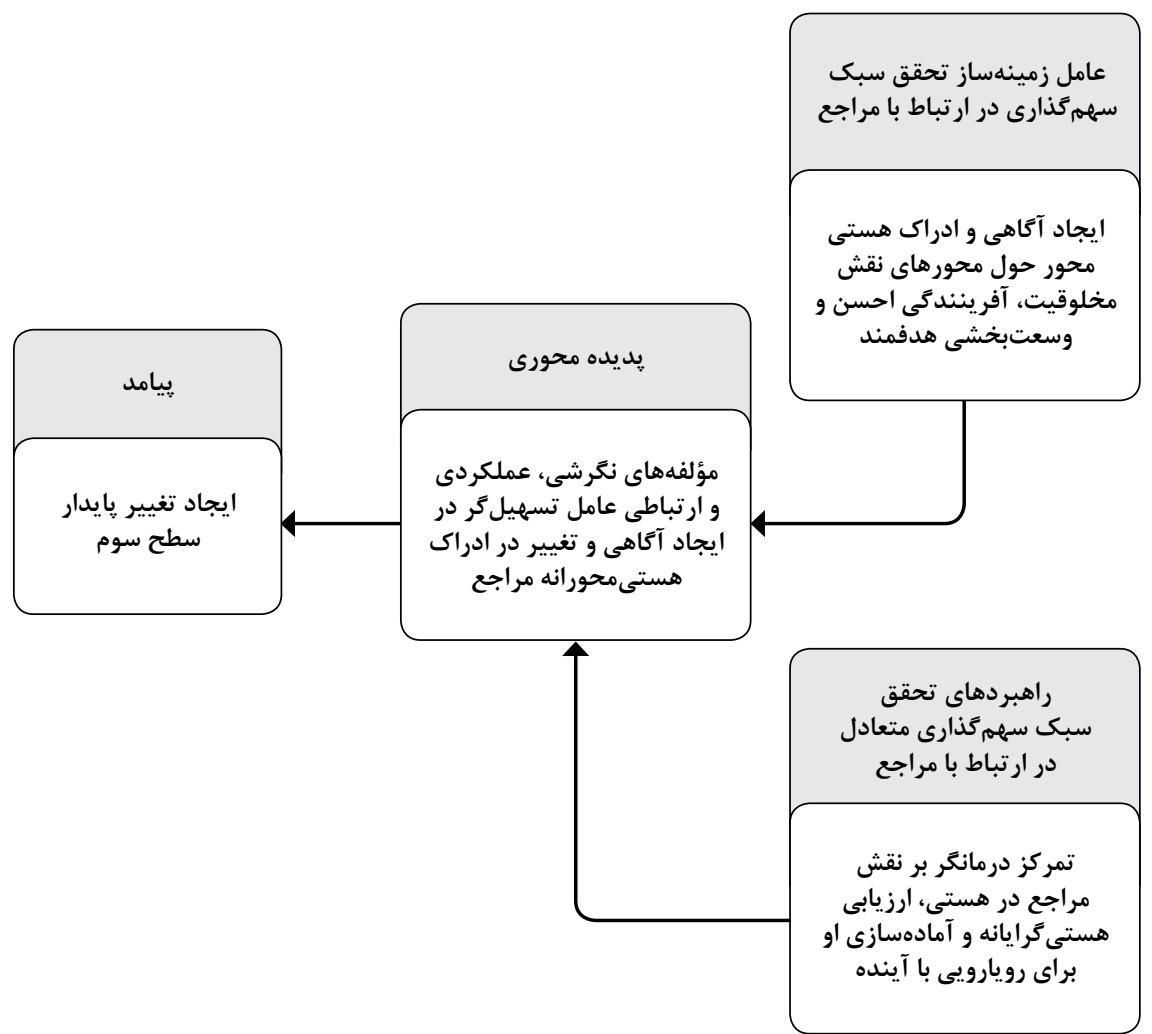

شكل ا. الكَى مفهومى ايجاد تغيير پايدار از طريق سبك سهم كذارى مشاور در ارتباط با مراجعان

سؤال سوم بروهشش: اعتبار درونى الكوى مفهومى ارائه شده يِير امون ايجاد تغيير

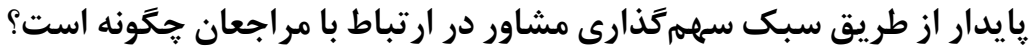

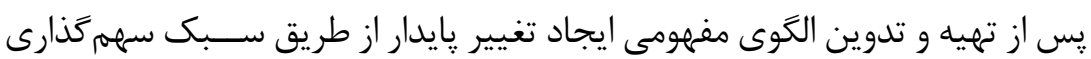

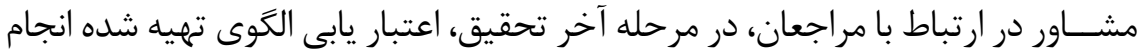

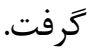
اعتباريابى فرايندى اسـت كه طى آن الكَى طراحى شده از طريق ارزيابى درونى

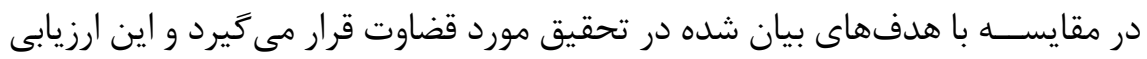

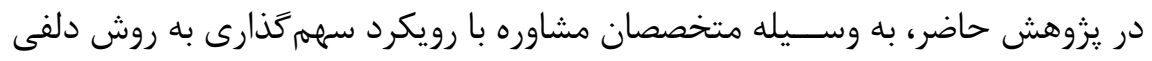

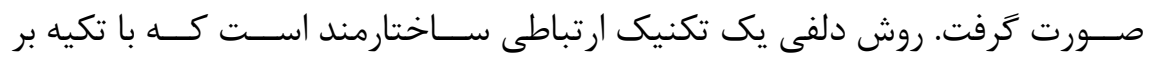


همانديشـى خبر ₹ان و جمع آورى و طبقهبندى دانش موجود در نزد آنها ابداع شده و توسعه يِيدا كرده است و از طريق مصاحبه و يا توزيع يرسشنامههايى در بين اين افراد و بازخورد كنترل شــده ياســخها و نظرات دريافتى صورت مى گيرد. به اين منظور در كل فرايند استنتاج و تدوين الكو (و نه صرفاً جداى از آن و در آخر كار)، محقق تلاش كرد اين هدف را مدنظر داشــته و يس از هر بار اســتـنتاج، تدوين و نَارش قسمتى از تحقيق، سؤالات كلى براى ارزيابى ميزان ساز گارى و همخوانى درونى مؤلفهها، عناصر و فرايند اســتنتاج شده را متتناســب با مرحلهاى كه يروهش در آن قرار دارد، به همراه يافتههاى نغارش شده به مؤلف الگو (اسمعيلى) و أ نفر از متخصصان مشاورهاى تعليمى يافته تحت رويكرد ســـهمَذارى كه اشراف نظرى بالايى دارند، ارائه دهد. كه در هر بار ارائه يفتهها به متخصصان، در صورت داشتن زمان كافى، محقق با آنها ييرامون نظرات تخصصى شــان كفتخوى حضورى صورت داده و در غير اين صورت، از آنها درخواست

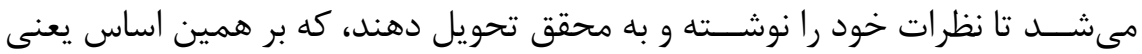
بازخوردهاى دريافت شده، يافتهها و الگوى طراحى شده مورد بازنخرى جندين بار قرار كرفته و اصلاحات لازم صورت گرفت.

\section{بحث و نتيجه كَيرى}

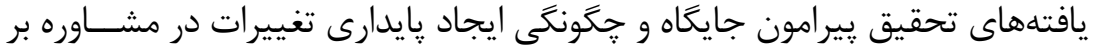
اساس سبك سهرمذارى مشاور در ارتباط با مراجع نشان داد كه بهنظر نيل به اين هدف، نيازمند سطحى از تفكر مرتبه سوم هستيهم كه در آن به درمانگر انى نياز است كه از طريق سبك مشاورهاى خاصى از طريق مشاركت و همراهى با مراجع، باعث ايجاد فراديدگاهىى' در آنها شـــوند كه طلى آن به تأثير ارتباطات گســـترده تر شامل سيستهمهاى اجتماعى و يويايىهاى قدرتى و معانى جمعى يى برده و بتواند مجموعه زَينههاى جايخزين درون

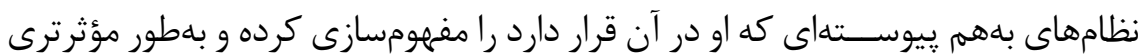
به مسائل پاسخ دهد. از آنجا كه اين فرايند آتاهى افزايى در مورد ارتباطات فرد با جهان خارج از طريق الكوها و ســـــهاى مشاورهاى مختلفى تواند امكان يذير شود، اسمعيلى

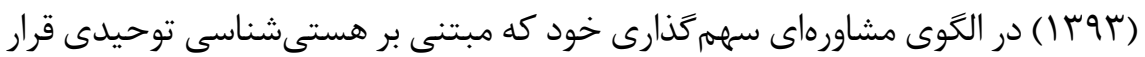


دارد، بيان كرد مبتنى بر ســبك سهم گذارى متعادل مى توان به اهداف مشاورهاى ايجاد تغييرات بايدار در مراجعان دست يافت كه يافتههاى تحقيق حاضر نشان داد مؤلفههاى

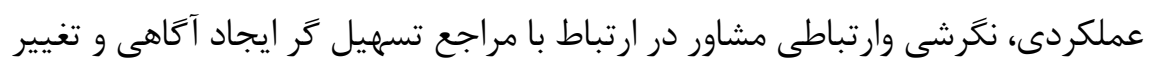

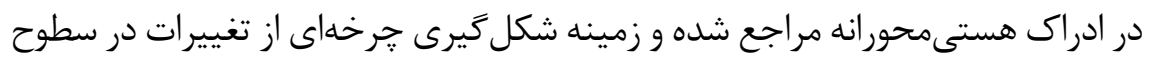

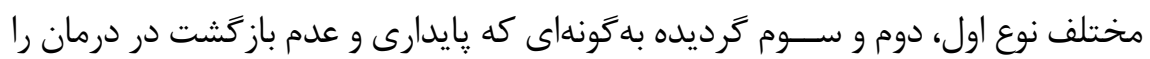
مى توان يیشبينى كرد. يادآور شـــند كه نيز نيل به اين سطح از آكاهى (Travis \& Wilbanks, Kates, 2012)

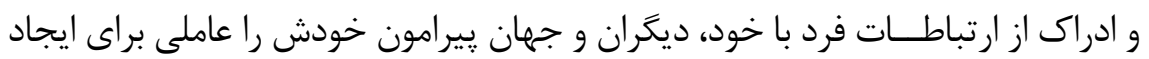

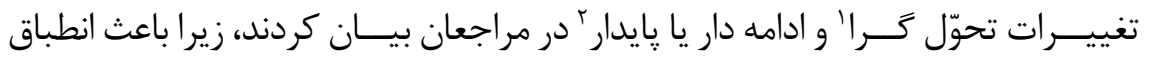

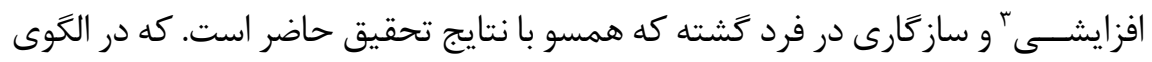

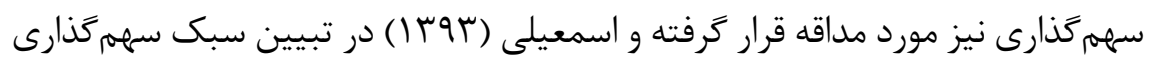

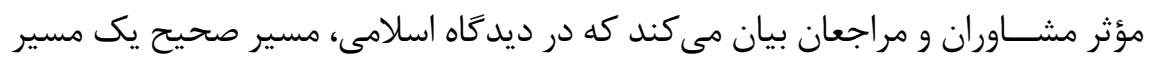

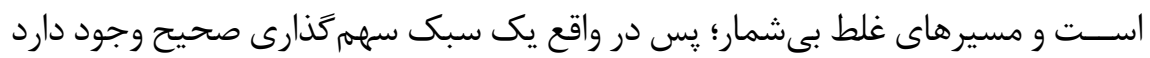

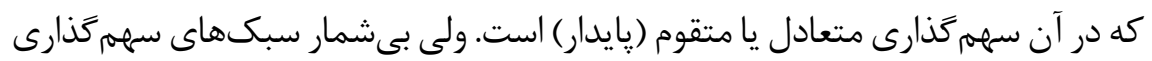

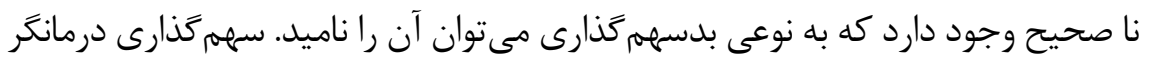

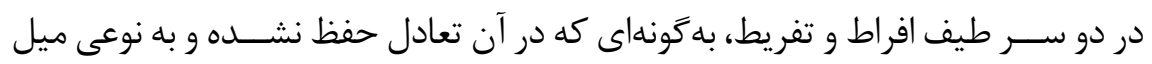

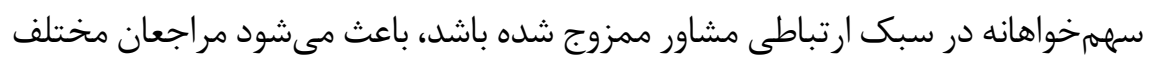

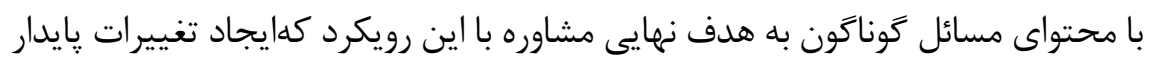

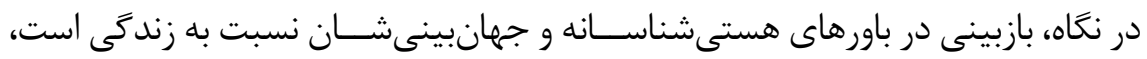

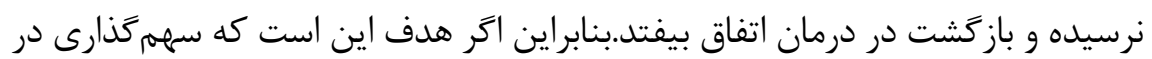

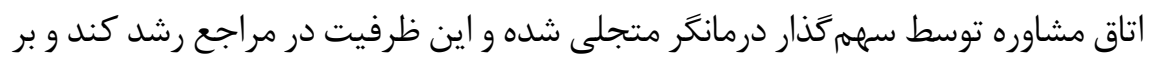

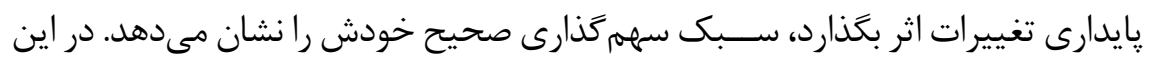

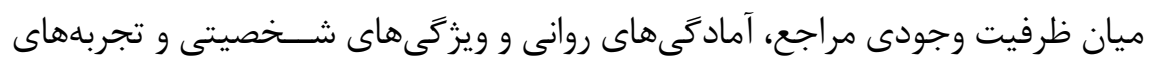

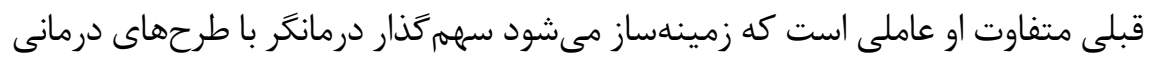

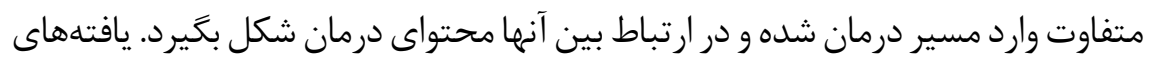




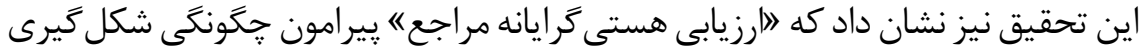
مسأله و بافت ايجادكننده آن بهعنوان يكى از مؤلفههاى عملكردى مشاور باعث مىشود كه مشاور علىرغم 》داشتن هدف مشخص و معيار عمل "در فرايند مشاوره، امسيرهاى متعددى را براى رسيدن به هدف ها در نظر گرفتن آمادگى هاى شخصيتى و نوع مسأله مراجع مدنظر قرار داده كه تعيين مى كند درمانگر مستقيهم وارد تغيير نوع سوم شود. در

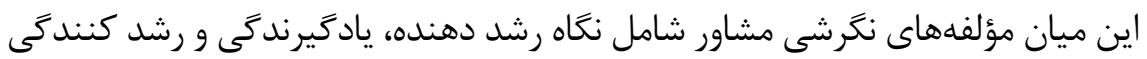
خود را داشتن، با تمركز بر نقش خود مراجع در هستى و مسئوليت يذيرى و آزادى او براى موى انتخاب، بهعنوان مؤلفههاى نكرشى مشاور وارد مسير درمانى شده و با مؤلفههاى ارتباطى مئى مؤثر شــامل ارتباط ملازمانه، همدلانه، محترمانه و متوجهانه براى درك و فهمم مراجع و

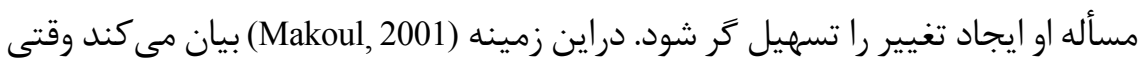
ارتباط مؤثر با مراجع برقرار شـــود، مشـــل او دقيق تر شناسايى شده و ييروى از درمان بالاترى در او حاصل خواهد شد. در نتيجه مشكل خود و انتخابهاى درمانى را بهتر درك كرده و تغييرات سريع تر و يايدارتر رخ مى بدهد. (Engel,1977) نيز در الكوى زيستى روانى اجتماعـى كه درباره عوامل مؤثر بر رضايت از درمان توضيح داد، به عاملى به نام ييروى از درمان اشاره نمود كه در آن افرادى كه ييروى از درمان بالاترى دارند، به نتايج بهترى دست يافته و به تبع آن رضايت شان از مشاوره و ايجاد تغيير بالاتر خواهد بود كه همسو لهان با نتايج اين :يزوهش است.

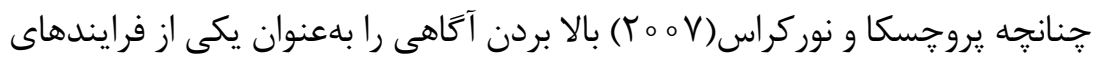

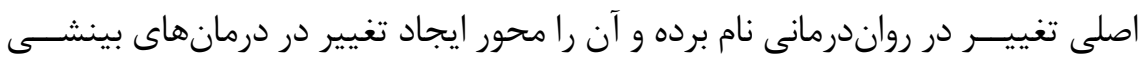
معرفى كردند. از آنجا كه فرايند افزايش آتاهى براى افزايش اطلاعات در دســترس افراد جهت ياسخ مؤثر به محركهاى در جريان زندگى است، يك مشاور با سبك سهمثَّارى در فرايند تغيير يا روى تغيير در ســطح تجربه فرد يا در ســـح بافت زندكى او فعاليت مى كند. كه اين تغييرات حول محور آكاهى افزايى هستى محورانه بهمنظور ايجاد تغييرات يايدار رخ مى دهد. البته در اين سبك مشاورهاى سمهمخذارى، علىرغم وجود شباهتهاى زياد براى شكســتن الكوهاى ناكارامد رفتارى و ارتباطلى، تفاوت اساســى با مبانى تفكر سيستمى دارد كه در آن نقطه گذارى حلقوى، تأثير و تأثر متقابل اعمال انسان را وابسته به عمل طرف مقابل توضيح داده بهَّونهاى كه در اين نوع از تفكر حلقوى و سيســـمى، دي، 
نظامها خود بهعنوان يك عامل تنظيم كننده و خودكردان در نظر كرفته مىشوند، بدين

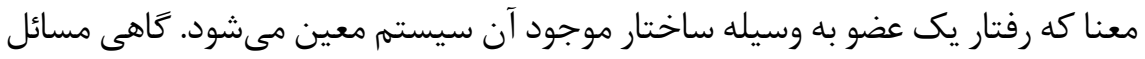

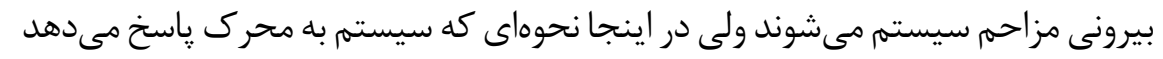

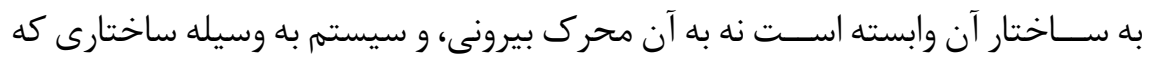

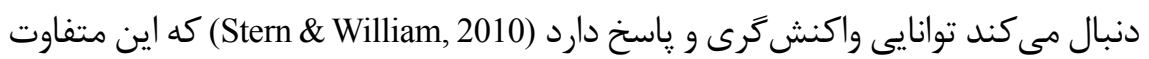

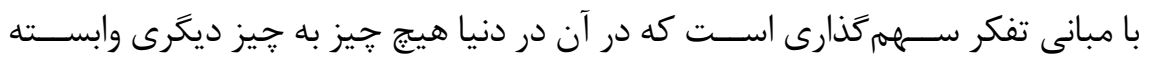

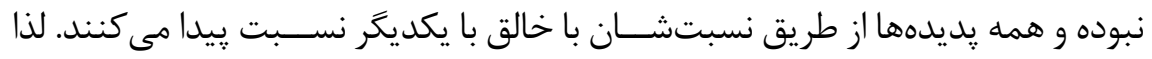

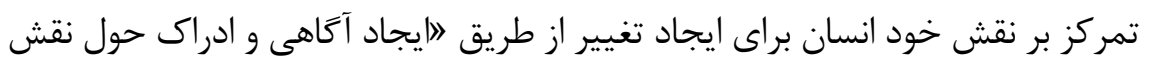

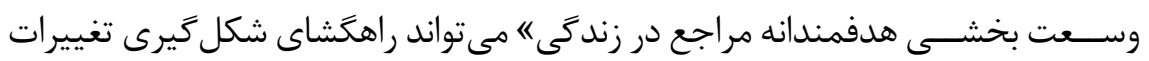
يايدار باشد.

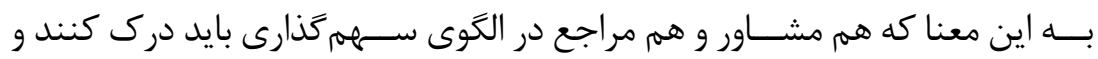

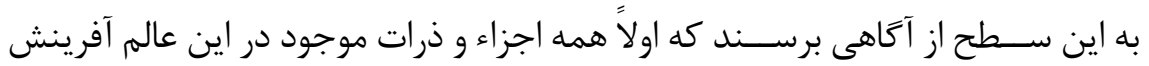

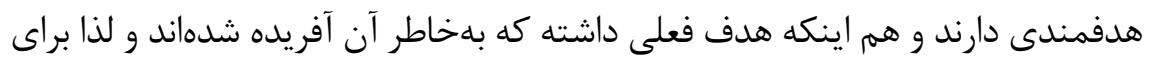

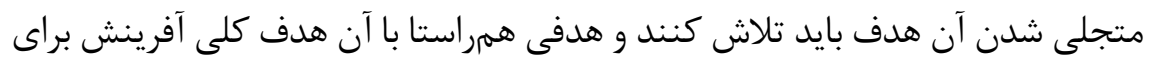

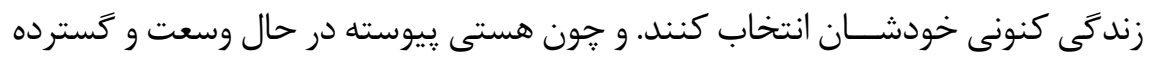

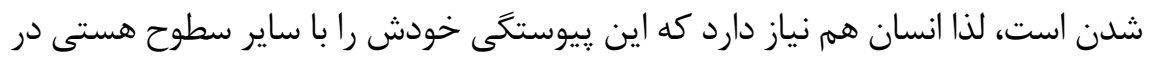

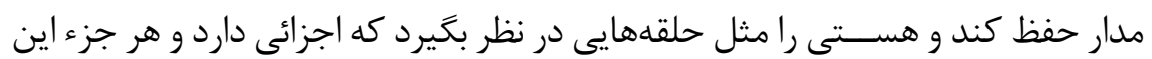

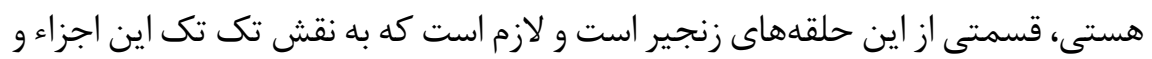

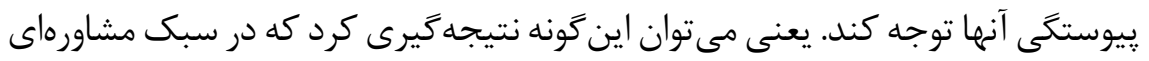

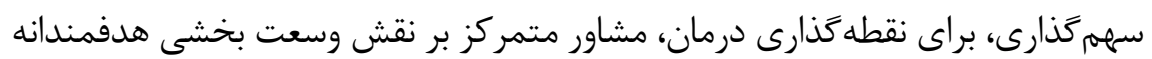

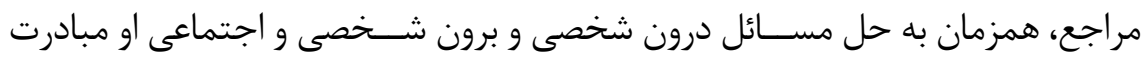

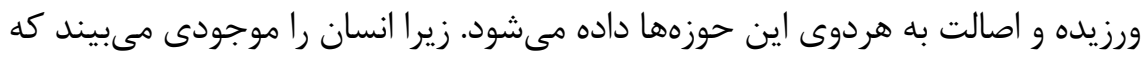

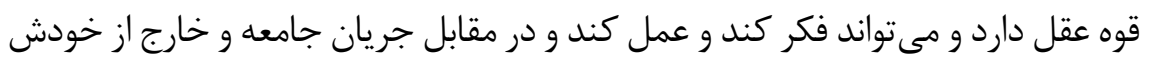

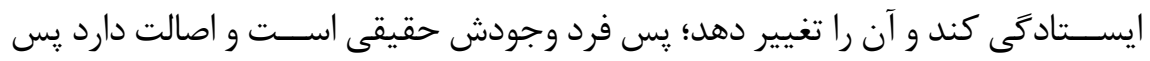

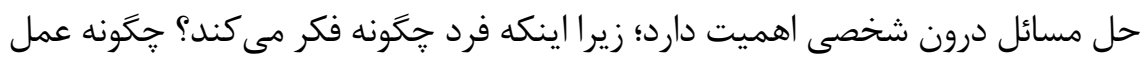

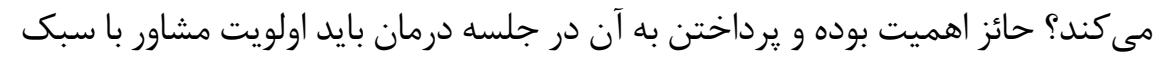


و از جهت ديخر، مســائل بيرون شـخص هم اهميت و تقدم دارد و اصالت با آن نيز است. زيرا جامعه جمع جبرى افراد تشكيل دهنده خودش نيست و يك شخصيت واحد و مستقلى دارد كه برآمده از روابط است و فراتر از تك تك افراد بوده و جامعه هم مىتواند جريان خود را بر سرنوشت انســان ها غالب كند. يس حل مسائل خارج از درون شخص هم اهميت زيادى دارد و در الخوى ســهم گذارى اين جامعيت لحاظ شــده و درمانگر با

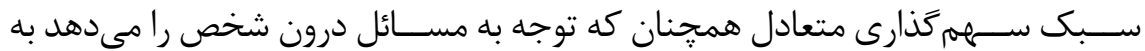
مسائل خارج از شخص هم اهميت داده و وابسته به موقعيت و مسألها يجاد كننده مشكل مراجـــع، درمانكر نقطهَـــذارى درمان را با تمركز بر نقش خود فــــد در ايجاد تغييرات صورت مىدهد. به اين معنا كه تبيينهاى درمانگر ســهمخذار بهصورت بين شخصى و درون شــخصى، يكيار جه بوده و براى نقطه گذارى تغيير، به نقش و مسئوليت خود فرد در ايجاد و شكل گيرى مسائل مىيردازد تا شاهد سطح بالاترى از تغيير باشيم كه در آن يايدارى و عدم باز گشت درمان را شاهد هستيهم. و اين زمانى اتفاق مى افتد كه طرحها يا جارجوبهاى جديد، تماماً در سيســتم اعتقادى و هويتى فرد نهادينه ميى شود كه بيانگر يك تغيير :ارادايميك است (Bess, 2006). يعنى :ييامد عزيمت از تغيير مرتبه اول و دوم به تغيير مرتبه سوم، مستلزم تغيير در ديدَاهها و معانى افراد و درنظر گرفتن زمينه اجتماعى و سازوكارهاى گفتمانى دربخيرنده آنها اســت(Mcdowell, Knudson-Martin \& Bermudez, 2019) كه با اتخاذ نوعى نغاه و جهانبينى جديد، بر فراروايتهايى كه افراد زندگىشان را بر اساس آن تنظيم و تنسيق مى كنند، تمركز مى كند. در نتيجه در اين مرتبه از تغيير، شيوه نكرش و تفكر فرد تغيير ييدا مى كند كه در الكوى سهم گذارى نيز يك جنين تغيير جهانبينى مدنظر قرار گرفته كه متمر كز بر ارزيابى هستى گرايانه مراجع، در مسيرهاى درمانى متفاوت بهصورت فرايند محور، خود را نشــان مىدهد. در يك كلام جون تغيير درجة سوم در زمينههاى خاص اتفاق مى افتد و با عواملى مانند بينش، امكان مقابله با يك مشكل و ايجاد ديدكاه جديد از مسئله، جهان و خود همراه است (Hanna \& Ritchie, 1995)، منجر به تغييرات يايدارترى شده كه به بهترين شكل با اصطلاح و ويزگى اتعالى" مى توان آن را توصيف كرد. تعالى شــامل فراتر رفتن يا خارج شدن از مجموعهاى از محدودهها، حصرها يا محدوديتهاى درك شده و تا حد زيادى از سيستمهاى معنايى قبلى كه تمامى اين عوامل توانايى مراجع 
در ايجاد تغيير و تحوّل در شــكل متعالى را تقويت مى كند. جنانجه اســمعيلى(بوس ا )

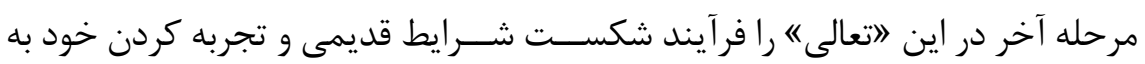

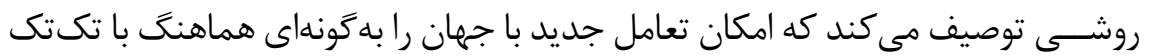

$$
\text { اجزاى هستى، فراهم مىسازد. }
$$

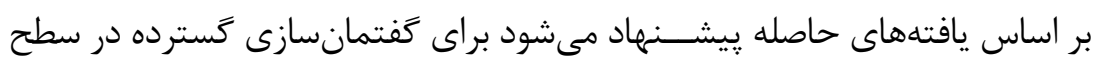

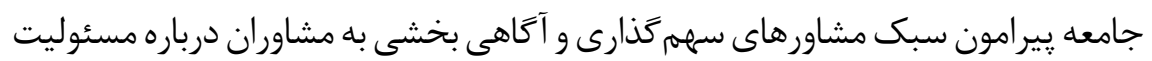

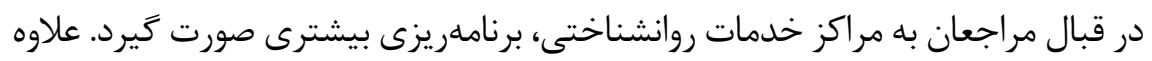

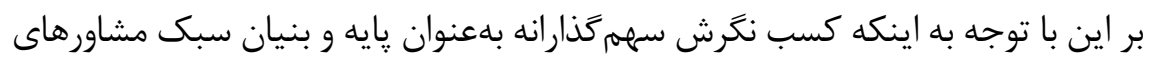

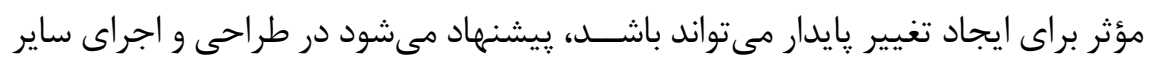

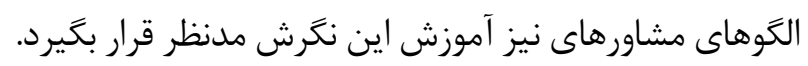

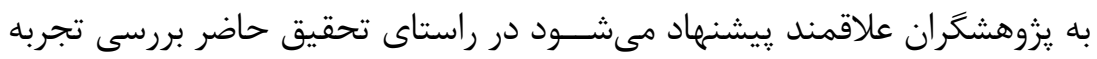

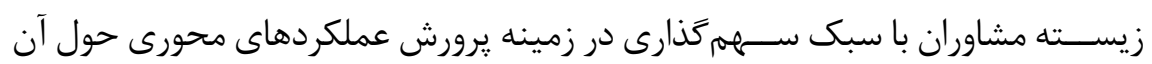

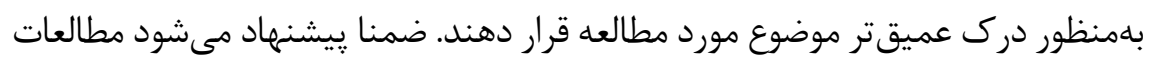

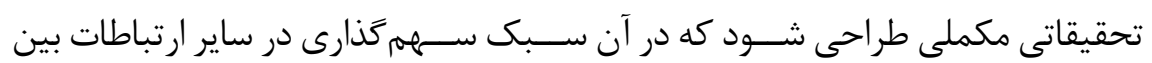

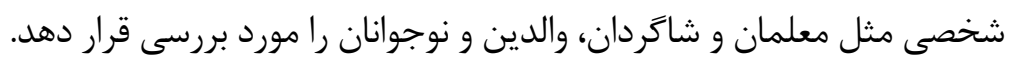

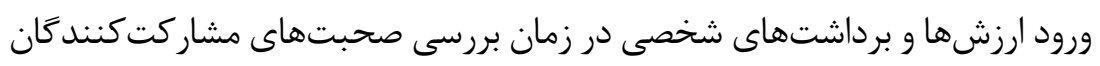

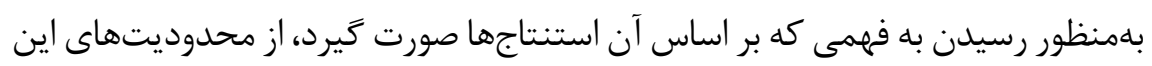

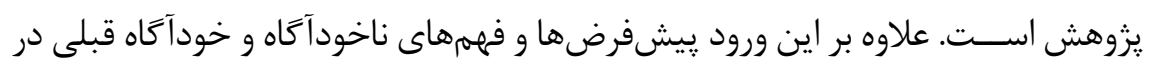

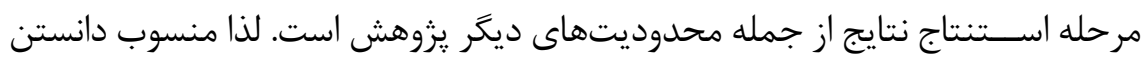
نتايج مساوى با برداشت كاملاً صحيح و دقيق محقق از آراى مصاحبهشوند محان نيست.

\section{تشَّر و قدردانى: تارئ}

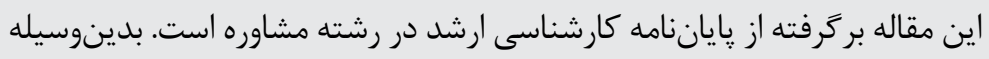

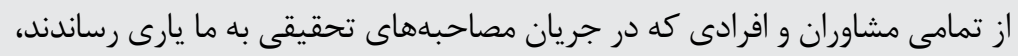




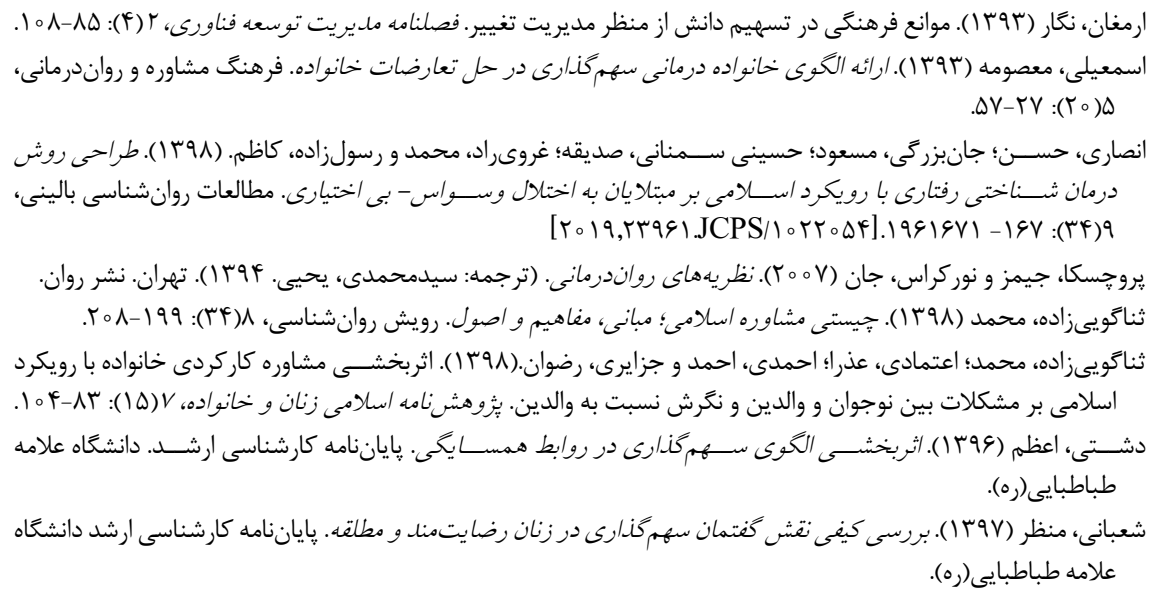

\section{REFERENCES}

Akingbola, K,. Rogers, S.E \& Balauch, A. (2019). Change management in Non Profit organization: Theory and Practice. Switzerland. Palgrava Macmillan.

Bess, K. D. (2006). The challenges of change in human service organizations: Identity, values, and narratives. ProQuest.

Dickerson, V. (2014).The advance of post structuralism and its influence on family therapy. Family Process, 53,401414.

Funnell, S.C \& Rogers, P.J. (2011). Purposfull program theory: effective use of theories of change and logic models. JohnWiley \& Sons.

Hofmann, S.C. (2006). The importance of culture in cognitive and behavioral practice. cognitive and behavioral practice, 13(4): 243-254.

Kates, R.W., W.R. Travis, and T.J. Wilbanks.(2012).»Transformational Adaptation WhenIncremental Adaptations to Climate Change are Insufficient.» Proceedings of the National Academy of Sciences of the United States of America 109 (19): 71567161.

McDowell, T. (2015). Applying Critical Social Theories to Family Therapy Practice. London: Springer.

McDowell, T., Knudson-Martin, C., \& Bermudez, J. M. (2019). Third-order thinking in family therapy: Addressing social justice across family therapy practice. Family process, 58(1), 9-22.

Murray, R. (2002). The phenomenon of psychotherapeutic change: Second-order change in one's experience of self. Journal of Contemporary Psychotherapy, 32(2-3)167-177.

Reynante, B., Bratton, M., \& Hein, L. (2017). From first-to third-order social change in development engineering: A case study. In IEEE Global Humanitarian Technology Conference (GHTC) (pp. 1-6).

Sankhe, A , Dalal, K., Agarwal, V., Sarve, P. (2017). Spiritual care Theory on quality of life in cancer patients and their caregivers: A prospective non-randomized single-cohort study. Religion and health, 56(2): 725-731.

Stern, S.B. \& William, J2007) .). Conservation of autonomy: Toward a second-order perspective on psychosomatic.

Tsoukas, H \& Papoulias, D.B. (2005). Managing Third order change: the case of the public power corporation in Greece. Long Range Planning, 38: 79-95.

Van de Ven, A. H., \& Poole, M. S. (2013). Explaining development and change in organizations. Academy of management review, 20(3), 510-540.

Watzlawick, P., Weakland, J., \& Fisch, R. (1974).Change Principles of Problem Formation and Problem Resolution. New York: (Norton).

Wendell, F ,. Cecil, B \& Robert, Z. (2004). Organization development and transformation: managing effective change. Mc Graw-Hill/Irw 